\title{
Responding to the urban transformation challenges in Turkey: a participatory design model for Istanbul
}

\author{
Ahmet Gün (iD) ${ }^{a, b}$, Burak Pak (D) ${ }^{b}$ and Yüksel Demir

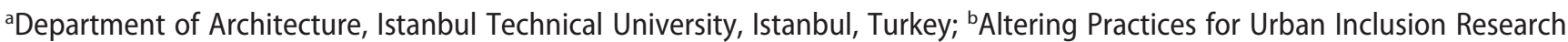 \\ Group, Faculty of Architecture, KU Leuven, Brussels, Belgium
}

\begin{abstract}
Turkey is vulnerable to disasters such as earthquakes, flood, and landslides. Millions of housing units are planned to be demolished and rebuilt in the next 15 years within the scope of urban transformation. The existing legal framework and implementations are hardly participatory and thus cause conflicts. The aims of this study are: 1) to address the weaknesses and strengths of urban transformation practices in Turkey critically with a focus on Istanbul, and 2) to develop a new participatory design model for urban transformation processes by making use of contextualised ICT-based participation tools and techniques. This paper critically maps and discusses urban transformation processes in Istanbul by tracing how these practices take place on the ground and considering the different perspectives of stakeholder groups. We present an applicable model that consists of a system of participatory actions, interaction environments such as an expert collaboration platform developed specifically for Istanbul's urban transformation process.
\end{abstract}

\section{ARTICLE HISTORY}

Received 26 June 2019

Accepted 27 February 2020

\section{KEYWORDS}

Citizen/public participation; participatory design; design empowerment; digital participatory platforms; ICTenabled participation; urban transformation; Istanbul

\section{Introduction}

Information and communication technologies (ICT) have been embraced as a development strategy for urban issues (Kitchin 2014). One of the main reasons for this paradigm shift is to develop more inclusive and participatory urban development processes by involving large numbers of stakeholders such as citizens, authorities, producers, and NGOs in large-scale urban projects.

Many technology-enabled public participation practices and forms provide an interactive and networked environment so that different stakeholder groups can participate in city-making processes making it possible to generate more democratic urban design and planning processes and more meaningful participation (Evans-Cowley and Hollander 2010). These opportunities come from the several features of digital technologies: new ways of gathering, storing and analysing data, and new modes of communication between citizens and authorities (Goldsmith and Crawford 2014). In the last two decades, a plethora of technology-enabled participatory tools, techniques, and applications such as web-based platforms, mobile participation apps, and digital participation games have been developed to facilitate the participation of citizens and other stakeholders (Poplin 2012; Desouza and Bhagwatwar 2014; Ertiö 2015; Falco and Kleinhans 2018). While these technology-driven solutions have been extensively used in developed countries for solving cityrelated issues or developing visions of cities, they have been used in the cities of developing countries for relatively basic urban issues. For example, ICT have been used to manage farming activities and collective knowledge sharing in Brazil, to carry out advocacy work by delivering sanitation services to informal settlements in South Africa and to share information and organise collective actions by activist organisations in Kenya and Argentina (Hirsch 2011; Mitchell and Odendaal 2015; Melgaço and Willis 2015).

Most of the highly populated cities in Turkey, like Istanbul, have been built on hazardous areas with highly vulnerable building stock since the $1950 \mathrm{~s}$ 
(Balaban 2019). The Minister of Environment and Urbanisation announced that 600,000 housing units in Istanbul are earthquake-prone and are planned to be demolished and then rebuilt in the next 15 years within the scope of urban transformation (Habertürk 2017).

The urban transformation process in Istanbul started in 2012. However, in the legal framework and current implementations, the urban transformation process is reduced to three basic physical construction steps with limited public participation. Previous studies have argued that this process centralises urban politics, excludes most of the citizens from the decision-making mechanisms and eliminates the participation of different stakeholder groups (Türkün 2011; Adanalı 2013; Elicin 2014; Unsal 2015; Balaban 2019; Tansel 2019). Thus, there is a need to find a novel way to empower citizens that not only involves large numbers of citizens in the urban transformation process by facilitating instant interactions between stakeholders (formal and informal actors) but also makes the urban transformation process more data-driven, agile and reflective. The use of ICTbased participatory design tools and techniques may be able to create the opportunities needed to achieve these goals.

The main objective of this study is to develop an ICT-integrated model that enables citizens to participate actively in the inspiration, ideation and integration stages of urban transformation processes in Turkey. This study uses the term, model, to describe a system of strategies, participatory tools and actions, user guidelines and success factors to enable replicable and scalable sets of interventions in the current framework. We aim to determine the weaknesses and strengths of Turkey's current urban transformation practices in terms of citizen participation and user empowerment, and propose a new and original way of participatory design for urban transformation processes in Turkey through the use of ICT-based participation tools and techniques. Given these aims, this study's primary research question is:

- How can urban transformation practices in Istanbul be made more participatory through the use of ICT?

With this question in mind, we deconstruct some key issues to offer an overview on state-of-the-art of the use of ICT-based participation platforms and their possible potentials for urban transformation processes in Turkey. This will require answers to these secondary research questions:

- What potentials do ICT-based participation tools and techniques have to support citizen participation in Istanbul's urban transformation?

- What problems and conflicts are caused by the current urban transformation practices in Istanbul from a participatory design perspective?

- What are the evaluative criteria to enable better and more effective participatory design practices?

In the next section of our study, we offer a state-of-the -art critical overview of ICT-enabled participation platforms and review the previous studies on Istanbul's urban transformation process. In the third section, we introduce our research methodology. Then, we do indepth analysis and map Turkey's complex urban transformation processes by identifying its conflicts and problems and discussing the possible potentials of ICT-enabled participation platforms in the context of Turkey. As a result, we are able to specify needs and requirements in different categories. In the fifth section, we elaborate on the research findings, identify the general framework, interaction environments and actions of the model, and describe key factors in the facilitation of better practices. In the final section, we discuss our findings and model and identify directions for future research.

\section{Literature review}

\subsection{ICT-enabled participatory design}

Recent advances in ICT allow alternative channels for distributing and gathering data, information and knowledge, potentially enabling citizens to make informed decisions and participate in design processes. Especially social media, Web 2.0 and digital mapping tools not only enable people to get involved in activities and share their interests and concerns but also expand the limits of their understanding and deploying space (Wallin et al. 2010; Bannon and Ehn 2012). These technologies also shift top-down design and planning towards a more participatory approach and potentially include informal actors and everyday practices (Ashley 2009; Meeus and Pak 2018). Thus, ICT can potentially enable citizen engagement and 
enhance the design and planning process by facilitating communication, interaction and collaboration between professionals and public (Houghton et al. 2014).

Web-based participation platforms, mobile participation applications, online participation games, social media networks are some of the technologies that are used to participate in the design and planning process. A plethora of terms have been used to describe citizen participation in the city-making process through the use of ICT, including: 'internet-based participation tools' (Evans-Cowley and Hollander 2010), 'technologyenabled participatory platforms' (Desouza and Bhagwatwar 2014), 'Geoweb 2.0 Platforms' (Pak and Verbeke 2014). In this study, we use 'ICT-enabled platforms' as an umbrella term. They can be defined as 'a specific type of civic technology explicitly built for participatory, engagement and collaboration purposes that allow for user-generated content and include a range of functionalities' (Falco and Kleinhans 2018, p. 52).

ICT-enabled platforms have some common features: internet use, the use of geolocation data and the logic of crowdsourcing (Gün et al. 2019). ICTenabled participation is based on crowdsourcing logic that defined by Saxton et al. (2013, p. 3) as: 'a sourcing model in which organizations use predominantly advanced internet technologies to harness the efforts of a virtual crowd to perform specific organizational tasks'. It depends on the collective intelligence of a crowd of web users (Brabham 2010). The terms, ICT-enabled participation platform and crowdsourcing platform, can be easily confused. Although both share some aims such as seeking information and insights of crowds, crowdsourcing platforms are not expected to give voice to the interest groups who are most affected by plans and decisions and to include groups that might otherwise be excluded (Seltzer and Mahmoudi 2013). This is why we choose to use the term, ICT-enabled platforms, instead of crowdsourcing platforms.

There are several studies have analysed the features and potentials of ICT-based participatory platforms in city-making processes (Desouza and Bhagwatwar 2014; Pak and Verbeke 2014; Ertiö 2015; Hasler et al. 2017; Falco and Kleinhans 2018; Gün et al. 2019). These platforms can potentially allow wider participation of citizens by lowering time and space barriers (Ertiö 2015). In traditional participatory design processes, one participant group, who are mostly male, middle-aged and already participating in society, may dominate participation processes so this creates representation inequalities in the community (Schröder 2015). ICT-enabled platforms make it possible to reach every community group in terms of socio-demographic profiles, age, income level, and ethnicity by providing them an equal right to participate in city-making processes. Moreover, the use of these platforms enables us to collect data that were difficult to gather such as information on perceptions, sentiments in real-time and all of these data can be visualised and analysed in more objective, accurate and easy ways (Hasler et al. 2017).

ICT-enabled platforms provide a wide variety of functions such as discussion forums, voting and ranking options, collaborative mapping tools, etc. (Falco and Kleinhans 2018). Citizens create discussions that could potentially lead to more questions that seek citizen answers on platforms (Desouza and Bhagwatwar 2014). Platforms are used as a dashboard where citizen responses are visible so it helps public agencies to understand citizen attitudes in the early stages of the projects. Moreover, these platforms provide design environments where citizens can add placemarks or tag content, draw polygons on the map and design 3D objects on digital models. Thus, platforms can facilitate to carry out participatory activities between citizens and governments and citizens become co-designers in urban development processes.

These platforms provide a follow-up mechanism that enables citizens to track whether their notifications, feedbacks or ideas used in the process (Gün et al. 2019). Platforms also empower citizens to follow all of the urban development steps and decisions taken concerning their areas. This not only makes the planning and design process more transparent but also prevent speculations and misunderstandings that undermine the process. All of these features make it possible to provide testimony of the public, exert pressure on public agencies to consider citizens' opinions and feelings on their decisions and help to transform the planning and design workflow into a collaborative and bottom-up process.

\subsection{Previous studies regarding urban transformation in Turkey and gaps filled by this study}

A wide range of researchers have studied Turkish cities' urban transformation processes with a variety of purposes: (1) examining legal regulations regarding 
urban transformation processes (Güzey 2016), (2) analysing the power relations and policies of urban transformation processes in the context of market-driven and top-down approaches (Türkün 2011; Lovering and Türkmen 2011; Elicin 2014; Tansel 2019), (3) reflecting on the discourse of urban transformation processes and providing insights into their intentions (Saraçoğlu and Demirtaş-Milz 2014); (4) exploring the various factors that shape resistance to urban transformation processes (Karaman 2014), and (5) describing the challenges, risks, and consequences of urban transformation processes (Balaban 2019). These studies successfully uncover the hidden structure and problems of urban transformation processes, but they do not go beyond the analysis of current practices and make limited and superficial suggestions about how to improve them. Only Yildiz et al. (2018) have proposed a model by identifying several design elements that can be implemented in urban transformation processes and evaluated their possible contributions but the researchers did not sufficiently consider urban transformation components such as the legal context and current practices.

As we have seen in the literature, many studies have analysed urban transformation processes and presented important findings. However, none of the studies in the literature have proposed a model that is embedded in the legal framework, determines the problems and potentials of urban transformation processes from the perspectives of multiple stakeholders, and identifies the key elements and issues that will lead to better practices. This study is intended to fill four gaps in theory and practice:

(1) developing a participatory design model that is embedded in the legal framework,

(2) identifying technology-driven solutions that will contribute to the success of urban transformation practices in Istanbul,

(3) designing an operational framework, use cases and user interfaces for an expert collaboration platform that is particular to Istanbul's urban transformation process,

(4) developing evaluative criteria for better participatory urban transformation practices in Istanbul.

\section{Methodology}

Our research methodology has three main phases: analysis, model proposal (synthesis) and testing. This study is a reflection on the first two phases. In the final phase (phase 3), the proposed actions will be tested with the collaboration of several municipalities. These phases are informed by feedback from legal authorities, governmental actors and potential users.

In this study, the literature review involved two stages of investigation. We firstly reviewed the literature (Section 2.1), focusing on the current state of ICT-based participatory design. In the second stage (Section 2.2), we did a state-of-the-art critical overview of urban transformation processes in Turkey. In this context, we reviewed the research to find out what is already known about our study area by doing a systematic search of the several databases (ACM, Scopus and Web of Science), some proceedings books relating participatory design, e.g. Participatory Design Conferences.

Then, we did an in-depth analysis and mapped Turkey's complex urban transformation processes to make them visible and clear (Section 4). To do this, we did a textual analysis of reports released by local and national governments, lawsuits, court decisions concerning urban transformation to understand the legal and institutional framework of urban policymaking and urban transformation practices. Then, we conducted semi-structured interviews with 14 authorities from 12 of Istanbul's government agencies. These interviews also helped to determine the problems identified by the regulators (authorities) and the users (citizens) of the built environment, and the hidden structure of urban transformation practices.

Based on the knowledge gathered in the first phase, in the second phase of our research, we identified the components of the model: the principles, architecture, actions and processes of the model, potential tools and technologies, and evaluation criteria (Section 5). We not only present an action flow chart to show how proposed actions embedded in the current urban transformation process but also demonstrate user interfaces of interaction environments (Figure 1).

To synthesise and develop our model, we adopted the institutional analysis and development (IAD) framework that has been used by scholars from multiple disciplines since the $1970 \mathrm{~s}$. The aims of the IAD framework are: 'to analyse the static situations shaped by existing rules and relating to an unchanging physical world and relevant community and to analyse dynamic situations where individuals develop new norms, new rules, and new physical technologies' (Ostrom and Hess 2007, p. 41-42). The IAD framework consists of three clusters of variables that affect institutional design and 


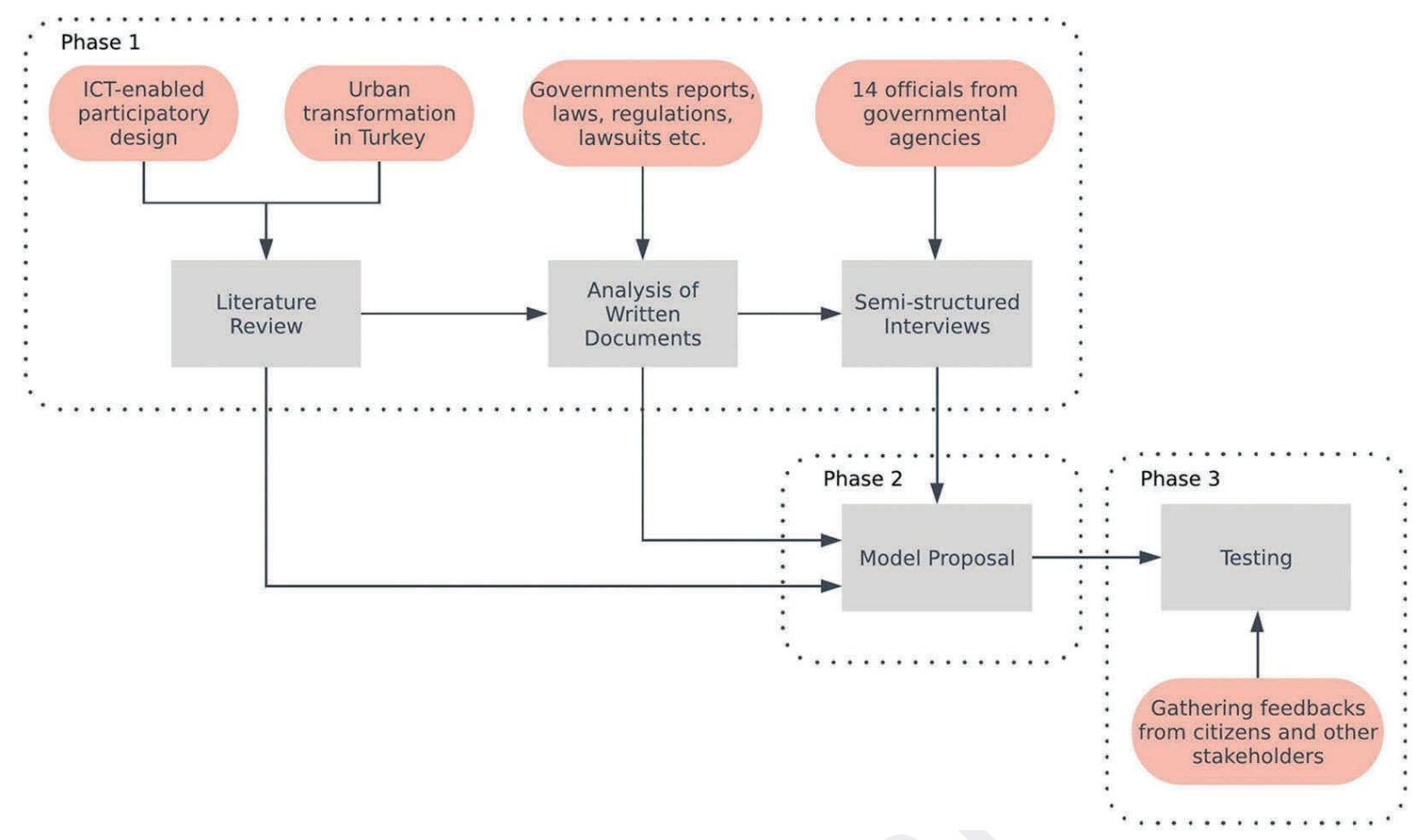

Figure 1. Framework of the methodology.

the patterns of interaction that take place within action arenas as following: (1) factors (physical/material characteristics, the attributes of the relevant community and the rules-in-use at several levels), (2) action arenas (action situations and participants), (3) outcomes (Ostrom and Hess 2007, p. 44-45). The aims of the IAD framework are in line with our model development objectives. This framework also seems well suited not only for the analysis of existing situations, but also for the development of our model, which is why we adopted it (Figure 2).

Based on our model development framework, we present the existing situation by identifying the rules-in -use (the current legal context and rules for the knowledge commons) (Section 4.1), attributes of the community (problems and potentials) from the viewpoints of the multiple actors involved (Section $4.2 \&$ 4.3). After integrating the knowledge from all of these phases, we identify requirements to guide our development of an ICT-enabled participatory model. To meet the requirements, we introduce the principles behind the model (Section 5.1) and identify the participatory actions that are embedded in a legal context and existing action flows and the available tools and techniques that can be used to realise these actions (action arena) (Section 5.2). We then address the evaluative criteria for examining urban transformation practices (Section 5.3).

\section{Urban transformation practices in Istanbul: identification of conflicts, potentials and requirements}

\subsection{Rules-in-use: the laws, regulations, actions and actors of urban transformation in Istanbul}

Turkey is situated on two main fault lines, the East Anatolian Fault and the North Anatolian Fault, so it has been vulnerable to earthquakes throughout its history (Erdik 2013). Since 1900, nearly 90,000 people have died in 78 earthquakes, 7 million people have been directly affected by them (Emergency Events Database 2019).

In 2012, the Government of Turkey enacted the Law Regarding the Transformation of Areas under Disaster Risks, hereafter the Disaster Law, to specify the principles and procedures pertaining to the rehabilitation, clearance, and renovation of urban areas and buildings that are prone to disaster (Official Gazette 2012). The Ministry of Environment and Urbanisation, which is a major authority in urban transformation, announced in 2017 that nearly half of 15 million housing units are under disaster risk. So the government has an ambitious plan to rebuild 500,000 housing units per year within the scope of urban transformation, 200,000 of them in Istanbul (Habertürk 2017). As of May 2018, a total of 188 


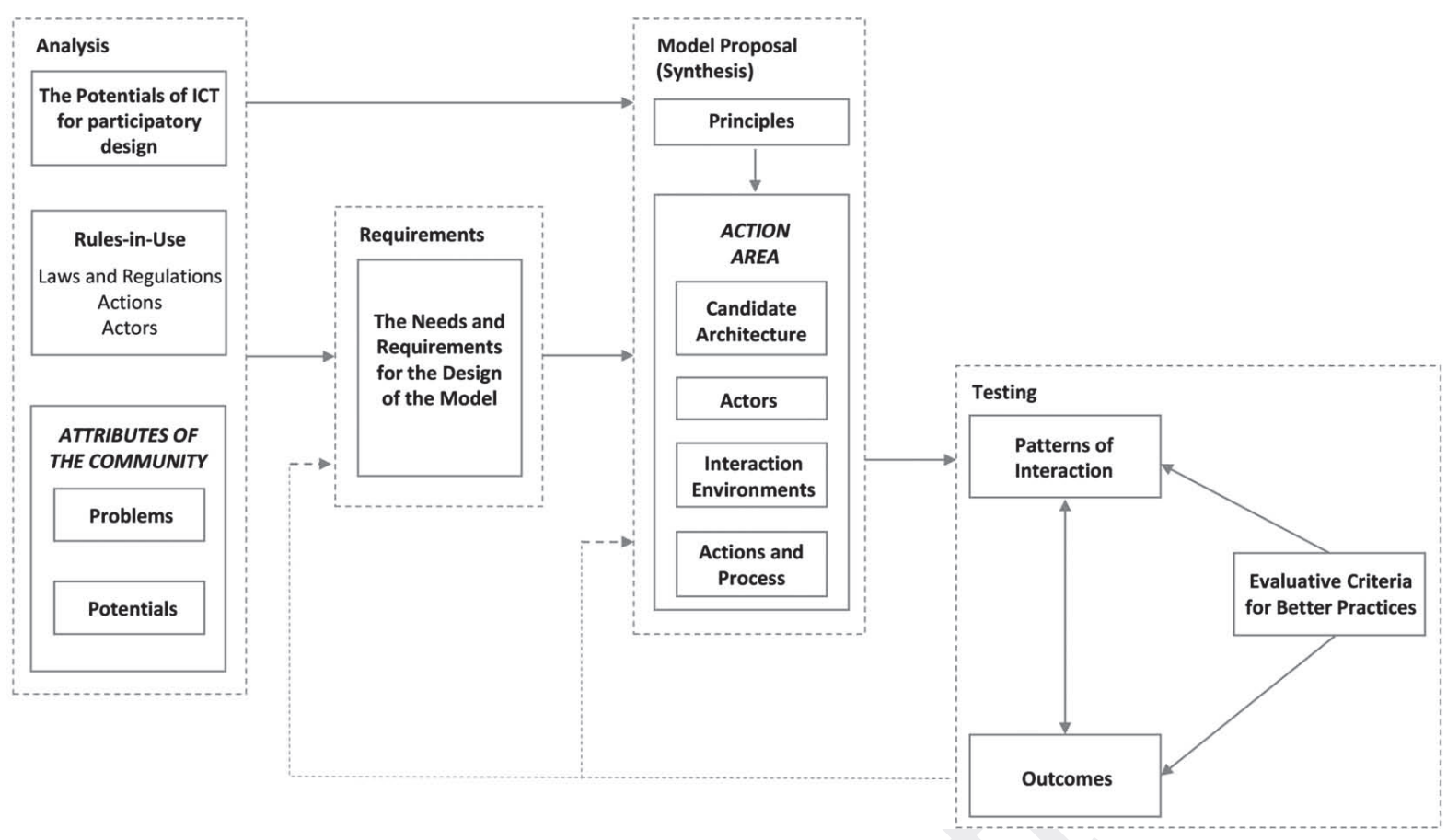

Figure 2. Development framework of the model (based on the IAD Framework, Ostrom and Hess 2007).

areas at risk have been declared by the Ministry of Environment and Urbanisation (Hurriyet 2018).

The legal framework and the implementations that have taken place up to now show us that urban transformation processes consist of three basic steps: (1) announcing areas at risk, (2) evacuating and demolishing buildings and (3) reconstruction. Five main actors play an active role in urban transformation: the Ministry of Environment and Urbanisation, municipalities or the mass housing authority (TOKI), design \& planning teams, residents and contractors. By law, the Ministry has the authority to organise urban transformation actions. District municipalities, metropolitan municipalities and special provincial administrations can also carry out urban redevelopment activities with the approval of the ministry (Official Gazette 2013). Design and planning teams prepare planning and urban design projects that consider the basic needs of the urban area, and these projects must be approved by the Ministry. Then, there are negotiations between the responsible authorities and the citizens, and when they reach an agreement, the buildings are evacuated, and construction is done by contractors (Figure 3 ).

\subsection{Problems and conflicts}

Urban transformation process still has not been accomplished as desired for several reasons. As Figure 3 shows, the only participatory activity offered by law is negotiation with the responsible authorities, which usually restricts citizen participation to one-sided information exchange. Thus, there is no mechanism that enables large numbers of participants to express their needs, desires and proposals concerning the renewal of their neighbourhoods. Nor are there any facilitators who are responsible for conducting participatory activities, mediating complex actions and mitigating conflict between different interest groups.

The current law and practices have been subject to a great deal of criticism. First of all, citizens have been exposed to urban transformation processes that impose authoritarian, top-down decision-making and eliminate any opposition by civil society (Elicin 2014). Second, the formal process minimises the role of critical experts and excludes public participation in the design and implementation of projects (Tansel 2019). Third, the central authority has been unwilling to coordinate and share data with other governmental institutions, universities and the public (Balaban 2019). In reaction to these issues, neighbourhood associations have organised protests and petitions against to urban transformation projects through the use of social and news media, and in some cases, they clashed with security forces (Karaman 2014). Many residents and neighbourhood associations have taken legal action by bringing lawsuits following the designation of their neighbourhoods as areas at risk of 


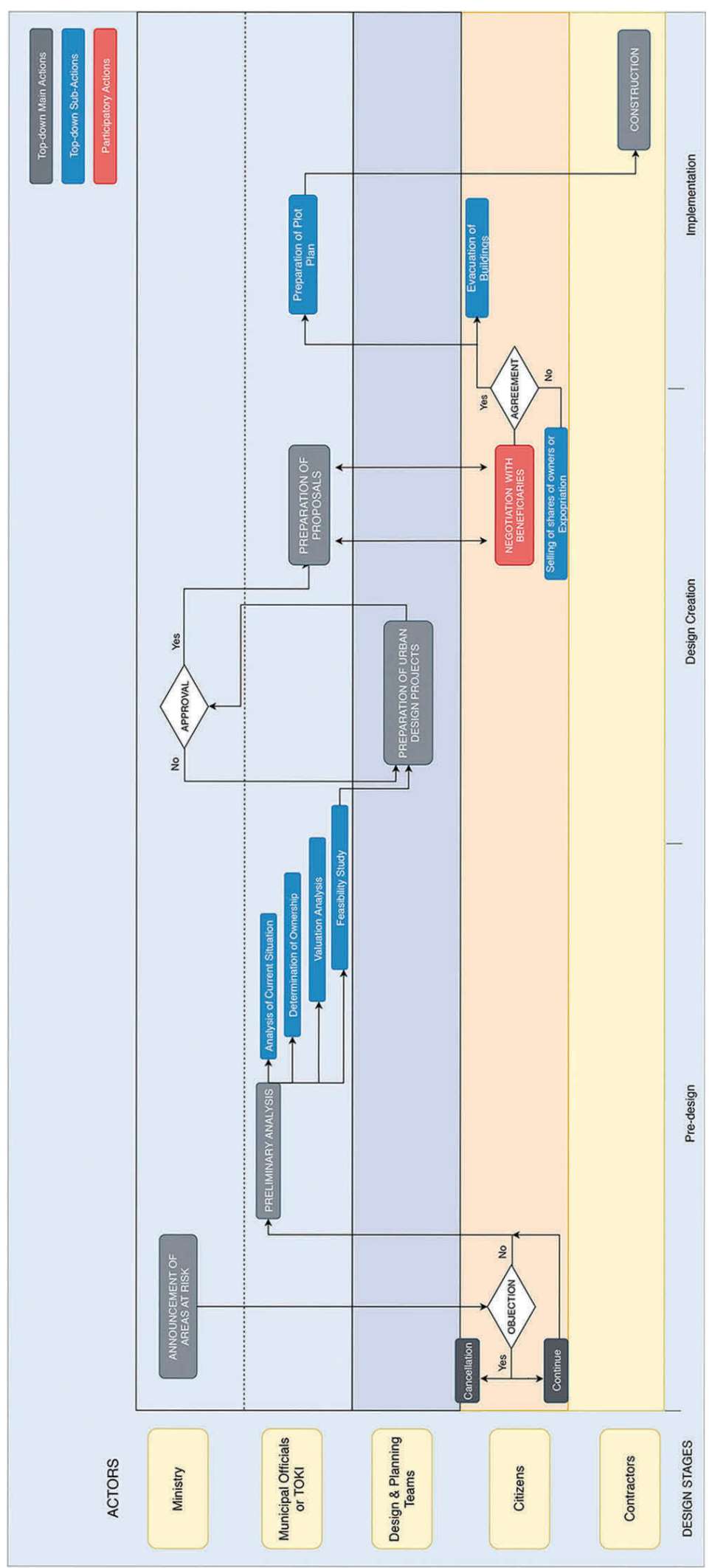

Figure 3. The current process for the redevelopment of large urban areas (prepared by the authors based on the Disaster Law). 


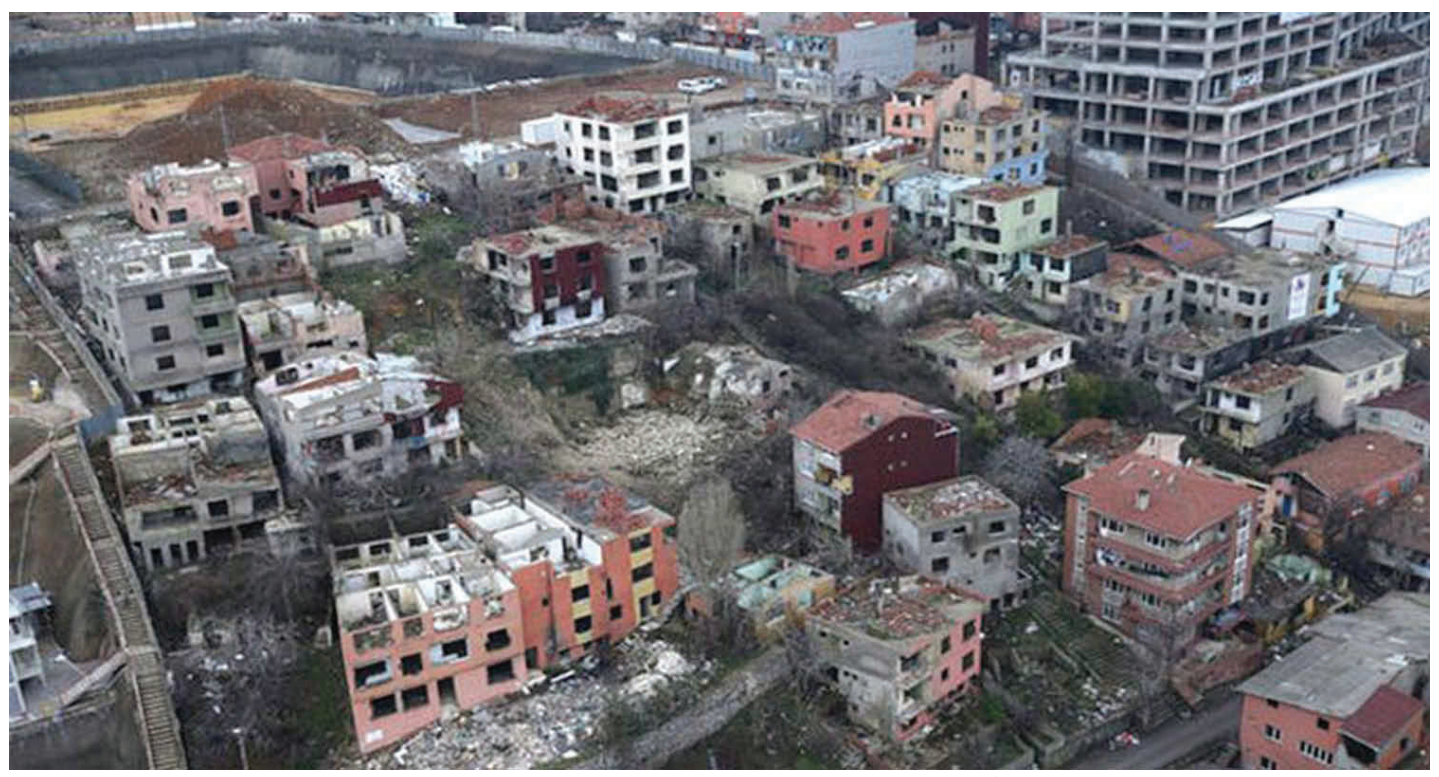

Figure 4. One of the urban transformation projects in Istanbul that could not be completed due to the disagreement between stakeholders (Yeniemlak 2017).

natural disasters. Due to these lawsuits, a plethora of area at risk designations had to be cancelled, which hampered the urban transformation processes (Figure 4).

By adopting a multi-dimensional perspective to identify problems, we study this process not only from the perspectives of the users of the built environment (residents) but also from the viewpoints of the regulators (authorities) and producers (design teams and contractors) involved in the city-making process. To do this, we first identified the problems and conflicts from the viewpoint of the regulators. We conducted interviews with 14 officials ${ }^{1}$ from 12 of Istanbul's government agencies.

The involvement of large numbers of citizens in negotiations inherently requires a large amount of time and space. Gungoren Municipality spent two years conducting negotiations (Official 6, personal communication, 30 January 2019). Carrying out negotiations with neighbourhood representatives not only saves time, but can also win the trust of neighbourhoods (Official 5, personal communication, 28 January 2019). The lack of strategies to prevent speculation and gossip is the other reason behind its failures. As a result, speculation replaces reality, creates misunderstandings and slows the urban transformation process (Official 13, personal communication, 31 January 2019).

One interviewee said that some community groups avoid submitting their ideas and comments about urban transformation projects to the municipality's website because they fear that their shared data and private information about them may be used for surveillance by the authorities or misused by ill-intentioned groups (Official 9, personal communication, 23 January 2019). As a result, citizens tend to express their desires and expectations to national authorities such as the Turkish Presidency's Directorate of Communications or create social media networks (Official 12, personal communication, 4 February 2019).

Another problem to be addressed is the lack of an environment where different professional groups such as governmental agencies, municipal officials, and design teams can view all the collected data in a shared space, deliberate over project issues, interpret the data and make decisions based on collective intelligence. Moreover, as Figure 3 shows, there is a lack of actors who manage workflows and other actors, determining the components of an environment that enable direct collaboration opportunities to different expert groups.

The current urban transformation process has also caused problems for the design and planning teams. First, Istanbul's urban designer and planners can only access and utilise very limited data sources such as the physical analysis and statistical data at the urban scale. They are expected to prioritise basic needs regarding the number of required housing units, the area needed for accommodation or public facilities by considering the development plans approved by the Ministry. They cannot access data related to the needs and preferences of 
users, or the value of the socio-spatial and cultural context. Since human-centred and contextual data are not used in the design process and projects are designed under many constraints imposed by the central actors' top-down approach, the design quality of urban transformation projects is low.

\subsection{The potentials of ICT use for urban planning and design in istanbul and emerging changes}

As stated in Section 2.1, many opportunities and solutions have been offered by technology-driven participatory tools and techniques in the city-making process. Their use can foster wider participation of Turkish citizens by lowering time and space barriers, providing representation equality in community, and offering many functions to make the urban transformation process more participatory, transparent and objective. In recent years, some changes have emerged in Turkey concerning the use of ICT and citizen participation. Turkish citizens are prominent users of the internet and social networks and acquainted with the recent advances in ICT. Turkey has 56 million internet users, which is $70 \%$ of its population (Statista 2019). It has a $60 \%$ social media penetration ratio, 2 hours and 59 minutes average daily mobile internet usage and 3 hours and 1 minute average time spent on social media (Kemp 2017). They also tend to express their desires concerning urban transformation areas on webbased platforms and social media channels. These facts and figures indicate that Turkish citizens can be motivated to use ICT-enabled participation tools and techniques in the urban transformation process.

The government of Turkey has recently made several efforts to improve its forms of governance policies. In 2019, the President of Turkey recently unveiled a local government manifesto to decentralise the planning and design process with the attention of social demands. Four of its eleven items are closely related to the intersection of citizen participation, urban transformation, and ICT. Furthermore, as per 2020-2023 National Smart Cities Strategy and Action Plan (2019), open governmental data will be liberated in Turkey to increase public participation and provide accountability and transparency. To do this, several government entities plan to develop the National Open Data Sharing Platform. This plan also includes some items regarding public participation in urban transformation processes. According to this plan, ICT-based technology innovations will be used to increase awareness about the effects of urban transformation decisions and empower citizens in participatory design processes.

In addition to these potentials, our study revealed that a limited number of technology-driven experiments with enabling participation in the analysis and early design phases of the urban transformation process have already been conducted by the municipalities in Istanbul. While Bayrampaşa Municipality has developed and used an expert collaboration platform that enables experts to see project proposals, to share data concerning negotiations, Istanbul Metropolitan Municipality has presented three-dimensional design alternatives on digital models to citizens at its information office to share information with citizens and collect their feedback concerning project alternatives (Official 7, personal communication, 6 February 2019; Official 2, personal communication, 7 February 2019).

\subsection{The needs and requirements for the design of the candidate architecture of the ICT-enabled participatory model}

The success of the participatory design solutions lies in identifying the user-specific requirements and incorporate them into design processes (Thinyane et al. 2018). In this study, we identified requirements to guide our development of an ICT-enabled participatory model by crosschecking the practices, problems, and potentials of the current urban transformation process. The requirements for Istanbul's urban transformation process concern: (1) citizen participation, (2) the civic data that belongs to citizens and their neighbourhoods, and (3) expert collaboration (Table 1).

\section{An ICT-integrated Participatory Design Model for Urban Transformation Areas in Istanbul.}

In this section, we propose an ICT-integrated participatory design model that meets our requirements and can contribute to the success of Istanbul's urban transformation process. In this context, we firstly introduce the principles behind the model. Then, we identify the participatory actions that are embedded in the legal context and existing action flows and the available tools and techniques that can be used to realise these actions. We finally address the evaluative criteria for examining urban transformation practices in Istanbul. 
Table 1. The needs and requirements for the design of the candidate architecture of the ICT-enabled participatory model.

\begin{tabular}{|c|c|}
\hline \multicolumn{2}{|l|}{ Requirements for ICT-enabled citizen participation } \\
\hline $\begin{array}{l}\text { R. } 1 \text { The use of ICT-enabled participatory tools \& } \\
\text { techniques }\end{array}$ & $\begin{array}{l}\text { To involve large number of citizens and use their collective creativity and experience in } \\
\text { the design process without making a great effort }\end{array}$ \\
\hline $\begin{array}{l}\text { R. } 2 \text { The use of technologies that are already } \\
\text { widespread in the community }\end{array}$ & $\begin{array}{l}\text { To get larger community groups to participate through the use of technologies already } \\
\text { used extensively by the city's population, such as mobile devices, social media and } \\
\text { web-based platforms }\end{array}$ \\
\hline \multirow[t]{4}{*}{$\begin{array}{l}\text { R. } 3 \text { The provision of transparent process and } \\
\text { effective communication strategies }\end{array}$} & $\begin{array}{l}\text { To prevent speculation and ill-intentioned groups who have already disrupted the } \\
\text { process and led to misunderstandings }\end{array}$ \\
\hline & $\begin{array}{l}\text { To empower citizens by allowing them to communicate and interact with formal actors } \\
\text { such as municipal officials }\end{array}$ \\
\hline & $\begin{array}{l}\text { To empower citizens by informing them about all the steps of urban transformation } \\
\text { processes }\end{array}$ \\
\hline & $\begin{array}{l}\text { To attract wider participation from Turkish citizens who do not have any experience } \\
\text { with involving in participatory design activities }\end{array}$ \\
\hline $\begin{array}{l}\text { R. } 4 \text { Involving additional actors as neighbourhood } \\
\text { representatives }\end{array}$ & To participate in decision-making process on behalf of community groups \\
\hline \multirow[t]{2}{*}{ R. 5 Ensuring equal representation } & To involve all interest groups in the participatory design process equally \\
\hline & $\begin{array}{l}\text { To prevent possible digital divides and unequal representation of different interest } \\
\text { groups such as immigrants and low-income communities }\end{array}$ \\
\hline \multicolumn{2}{|c|}{ Requirements for the Civic Data That Belongs to Citizens and Their Neighbourhoods } \\
\hline \multirow{2}{*}{$\begin{array}{l}\text { R. } 6 \text { Collecting multi-layered data about citizens } \\
\text { and their neighbourhoods }\end{array}$} & To make the design process more data-informed \\
\hline & To improve the design process's ability to reflect the attributes of community \\
\hline R. 7 Involving an additional actors as facilitators & $\begin{array}{l}\text { To mediate and facilitate the process and mitigate possible conflict between different } \\
\text { interest groups }\end{array}$ \\
\hline \multirow[t]{2}{*}{$\begin{array}{l}\text { R. } 8 \text { Defining the protocols for a knowledge } \\
\text { commons }\end{array}$} & $\begin{array}{l}\text { To specify the rules regarding who owns and has the right to access knowledge } \\
\text { produced as a commons, how knowledge commons are generated and preserved, } \\
\text { and how they are managed and governed (Hess and Ostrom 2007, p. 9). }\end{array}$ \\
\hline & $\begin{array}{l}\text { To protect participants' shared data and private information from the misused by ill- } \\
\text { intentioned groups. }\end{array}$ \\
\hline \multicolumn{2}{|l|}{ Requirements for Expert Collaboration } \\
\hline \multirow[t]{2}{*}{ R. 9 Developing expert collaboration space } & To allow different expert groups to download and view the collected data \\
\hline & $\begin{array}{l}\text { To provide a shared workspace that enables multiple expert groups to exchange } \\
\text { opinions and deliberate over project issues and thus provide collective decision- } \\
\text { making through collaboration }\end{array}$ \\
\hline $\begin{array}{l}\text { R. } 10 \text { Involving additional actors as project } \\
\text { managers }\end{array}$ & $\begin{array}{l}\text { To manage workflows and actors, identify the requirements that can possibly change } \\
\text { according to conditions of transformation areas, and monitor the data flows in the process }\end{array}$ \\
\hline
\end{tabular}

\subsection{General principles of the model}

After integrating the knowledge from our literature review, other similar studies and our findings, we identified several principles. Here, we discuss the four most essential principles that will help to make urban transformation processes more inclusive, participatory and objective: (1) ICT-enabled participatory design of urban transformation processes as a knowledge commons, (2) data-driven urbanism, (3) hypercontextual analysis and design, and (4) implementing blended strategies that combine digital and realworld actions.

\subsubsection{P.1 ICT-enabled participatory design of urban transformation processes as a knowledge commons (in response to requirement 8)}

The ICT-based innovations such as the internet, big data, and machine learning have caused to a centralisation of data that leads to problems concerning civic participation, users' right to their own data, and data privacy (Smith et al. 2017). Moreover, new modes of collecting, processing and disseminating spatial information bring about new problems regarding privacy issues (Elwood and Leszczynski 2011). In the big data era, people are increasingly concerned with transparency in data 
collection and in controlling flows of their individual spatial information and they are aware that any attempt at exerting this kind of control is futile (Leszczynski 2015).

Similarly in Turkey, some community groups avoid submitting their ideas to local governments' web-site for fear that their data may be used by ill-intentioned groups. Thus, in order to address the challenge of fostering wider participation of Turkish citizens, establishing trust is quintessential. Therefore, to specify the rules regarding who owns and has the right to access knowledge produced as a commons (Hess and Ostrom 2007), how knowledge is generated and preserved, and how they are managed and governed will play a critical role to establish trust in urban transformation processes.

In this context, the urban data, information, and knowledge produced in urban transformation processes should be regarded as a shared resource that belongs and is accessible to citizens and regulated as a knowledge commons. This commons will be organised following the National Smart Cities Strategy and Action Plan (2019). It is planned to be integrated into the National Open Data Sharing Platform 2020-2023 in the near future.

Users' data including their personal locational data, personal preferences and ideas regarding the project must be protected. To accomplish this, there is a need to provide a data flow mechanism that not only anonymises users' contributions but also eliminates the need for any central authority. Blockchain technology enables a decentralised network of peers that enable users to own and control their data (Zyskind et al, 2015). In the Blockchain environment, citizens' data protected by strong encryption and citizens are given the right to full control over their data (Zimprich 2018). These features show us that it provides important opportunities for protecting data privacy and preventing the misuse of users' information. We thus offer that, in our model, all of the data produced in the participatory design process managed through the use of Blockchain technology.

\subsubsection{P.2 data-driven urbanism (in response to requirements $3 \&$ 9)}

A great amount of contextual and actionable data can be produced and used in ICT-enabled participatory design processes. We adopt the data-driven, networked urbanism that makes an evidence-based approach possible and reduces political influence in decision-making so that urban issues can be driven by objective, neutral facts in a commonsensical and pragmatic way (Kitchin 2015). We intend to employ not only objective data such as records, physical analysis, and information that reflect the current situation in urban areas, but also subjective data such as social media data to get first-hand information about the views and insights of people that reflect their desires and needs concerning urban transformation projects. This not only gives design teams a better understanding of both the physical and social tissue of neighbourhoods and makes urban transformation processes more objective and fair but also helps to prevent speculations that already disrupted the urban transformation processes.

\subsubsection{P.3 hyper-contextual analysis and design (in response to requirements $1 \& 6$ )}

Extremely diverse community groups live in Istanbul with different ethnic backgrounds, lifestyles and daily habits. This diversity is inherently reflected in the characteristics of the city's built environments. In the urban transformation process, it is of utmost importance to recognise and consider these issues. Otherwise, the city's diversity and cultural values will be endangered or lost. In this context, we adopt hyper-contextual urbanism as a key design criterion in the design phase of urban transformation projects for recognising and valuing the unique socio-spatial characteristics of neighbourhoods and everyday practices.

\subsubsection{P.4 implementing blended strategies that combine digital and real-world actions design (in response to requirements $3 \& 5$ )}

Former studies have found that the ICT-enabled platforms can exclude citizens with low education levels as well as immigrants and low-income communities (Desouza and Bhagwatwar 2014; Schröder 2015; Pak et al. 2017; Nunes Silva 2018). ICT-based participation activities are usually (76\%) complemented by traditional participation activities such as face-to-face interviews, onsite design meetings, and referendums (Gün et al. 2019). The disconnect between participatory actions in digital and real atmosphere results in ignoring the potentials of the hybrid role that digital and real-world actions can play in participatory design processes (Foth and Brynskov 2016). All of these show us that the strength of ICT-based participation lies in employing both offline and online participatory techniques in city-making processes. 
In Turkey, everyday communication culture is dominantly oral rather than written (Kirlidog 2008). Moreover, citizens do not have any experience with involving in participatory design activities. These can lead to difficulties in attending a computer-mediated communication environment and therefore may cause digital-divides and representation inequalities. The use of these technologies may also lead to a shared sense of alienation in community (Foth and Adkins 2006). To involve all interest groups in community, including disadvantaged citizen groups, who have different backgrounds in terms of digital literacy, skills, language level, ability to access the internet, etc., and motivate them to participate in and express their concerns on social and spatial matters, participatory design actions are arranged on-site with these groups. Moreover, capacity development and training activities, such as organising workshops to train citizens about design issues and conducting collective visioning activities, should be arranged on-site with the involvement of the reliable actors in the community, such as urban activists, university researchers and students, especially in the early phases of the process. Social workers are mobilised to collect citizens' demands and thoughts orally from the field without collecting private information during on-site participatory actions.

These strategies not only enhance the citizens' trust in the process but also enable wider participation from all citizen groups. Thus, in our model, both technology-driven and traditional participation techniques, blended strategies, are implemented for carrying out proposed participatory actions.

\subsection{The components of the ICT-integrated model for Istanbul: candidate architecture, actors, interaction environments, actions, and processes}

Based on our analysis and principles of the model, we have identified a candidate architecture, actors, interaction environments, and participatory actions. We regard this model as a set of complementary actions that facilitate the urban transformation process and encourage stakeholder groups to get involved in the urban transformation process in a convenient way. To accomplish this, we considered the current legal framework and practices, and suggestions from municipal officials as resources for model development. Now we will introduce the model's candidate architecture.

\subsubsection{Candidate architecture}

The term, candidate architecture, is used to define: 'a particular arrangement of static and dynamic structures that has the potential to exhibit the system's required externally visible behaviours and quality properties' (Rozanski and Woods 2005, p. 17). Our candidate architecture was developed based on WebGIS that enables members of organisations to easily access and employ geographic data in a collaborative environment without the need for expertise to benefit from or contribute to the platform (Law 2014).

As mentioned in the previous section, our aim is to involve three groups of key components in the design process: citizen participation, the use of civic data that belongs to citizens and their environments, and expert collaboration. Our model is based on three main action types that encourage participants to get involved in participatory actions and facilitate the process: communication, a collaboration between different stakeholders and the co-production of design ideas. Moreover, based on the requirements related to the actors, we propose three additional actors, participation architects, citizens' assemblies and project managers, who take active roles in facilitating the process.

We intend to collect and generate data by making use of different technology-driven tools. Thus, we propose several environments where communication, collaboration, and co-production activities can take place between different stakeholders, called interaction environments, such as web-based platforms, mobile participation applications, and an expert collaboration platform (Figure 5). Another objective that has been pursued is to identify several participatory actions such as mapping the socio-spatial context and social media analysis that integrated into existing action flow by considering the relevant laws and practices.

\subsubsection{Actors}

Participatory design processes not only change the role of the citizens but also requires to reconsider the role of governments and the other actors (Foth 2018). Strategic actors can make a difference and provide real opportunities for specific situations in complex urban development practices (Healey 2003). In Turkey, the lack of actors who represent neighbourhoods in decision-making processes (requirement 4), facilitate and mediate the process (requirement 7), and manage the workflows and expert groups 


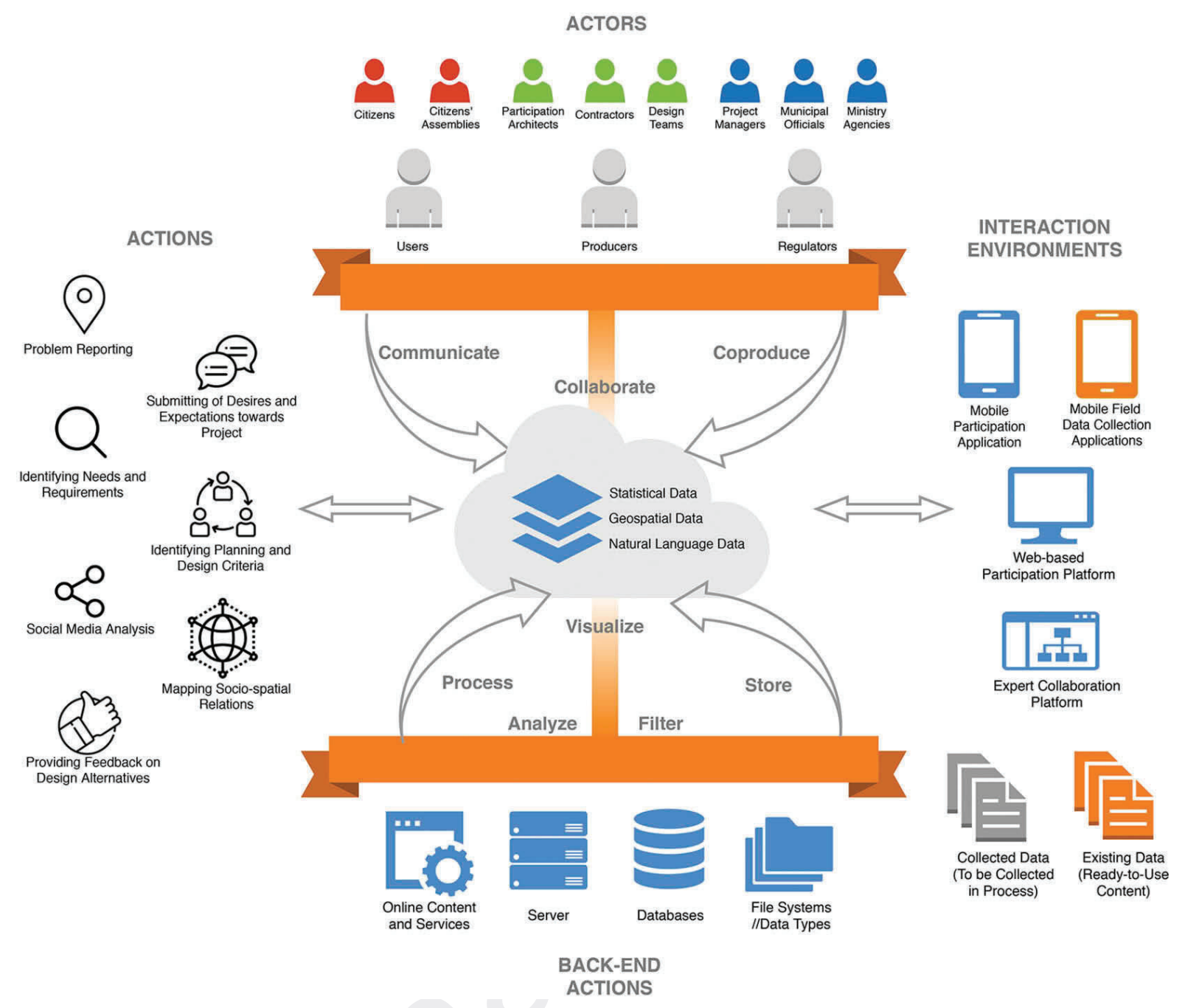

Figure 5. A candidate architecture of the model (based on ESRI webGIS collaborative cloud).

(requirement 10) has undermined the success of the process so far. In this context, we propose that three additional actors should be involved in urban transformation processes: (1) citizens' assemblies, (2) participation architects and (3) project managers.

The neighbourhood representatives are community leaders who have played a central role in saving time and winning the trust of communities in urban transformation processes (Official 5, personal communication). In Turkey, citizens' assemblies are recognised as official units by Municipal Law No. 5393, Article 76 to facilitate public participation and self-governance and carry out participatory activities in urban life (Official Gazette 2005). Citizens' assemblies should be considered the legal representatives of neighbourhoods that include different interest groups, so they are expected to participate in decision-making processes on behalf of community groups.
To mediate and facilitate the process and mitigate possible conflicts between different interest groups by conducting participatory activities, online or on-site, there is a need to involve facilitators as an additional actor in urban transformation processes. In this study, we use the term, participation architect, to refer to facilitators. A participation architect can be a single person or a group that consists of members with different backgrounds. They are not required to be architects or urban planners. Previous field studies regarding participatory design in Turkey show us that, citizen groups trust in university researchers and urban activist groups, such as Mekanda Adalet Derneği (Centre for Spatial Justice) and Bir Umut Derneği (One Hope Association), and tend to collaborate with these actors on carrying out participatory design process (Yalçıntan 2009). Thus, the involvement of 
the urban activists, university researchers and students within the group of participation architect can facilitate trust. In putting the universities and a 'live' design studio at the centre for managing the participation processes as a party without any benefits or income from the spatial production. This can possibly evolve into a non-profit spin-off under the frame of the university.

Moreover, there is a lack of actor who manages the overall urban transformation process that takes four years on average from the announcement of areas at risk to implementation. Thus, we propose involving an additional actor, project managers, who play a key role in managing the workflows and actors throughout the process. Project managers are also expected to identify the requirements that may change according to the conditions of transformation areas and monitor data flows.

\subsubsection{Interaction environments}

Current urban transformation processes have lacks and limitations when it comes to providing suitable interaction environments (requirements 1, 3, 6, 9). Thus, we offer four promising interaction environments (IE) to make urban transformation processes more inclusive, participatory, data-driven and transparent: (1) a cloudbased participation platform, (2) a mobile-based participation application, (3) mobile field data collection apps, and (4) an expert collaboration platform.

\subsubsection{IE 1. Cloud-based participation platform.}

We propose a cloud-based participation platform that is used for several actions. First, citizens will be informed about projects and action steps, and communicate with municipal or government agencies. Second, they can report problems about their neighbourhoods in categories such as security, living areas, and public spaces. They can also follow whether their notifications have been integrated into the process by checking interactive maps. Third, citizens create submissions to express their needs, desires, and expectations concerning the planning and design of their neighbourhoods, and view the others' submissions, leave comments, rate or vote for them by using functions offered by platform interface: (1) adding a placemark and descriptive text, (2) drawing a polygon on the map or (3) designing 3D objects on virtual models. Fourth, citizens view project alternatives prepared by design teams and provide text-based feedback concerning them (Figure 6). Since all information regarding urban transformation processes are shared with citizens transparently, and they are allowed to participate in the process, the speculation and gossip that undermined the process

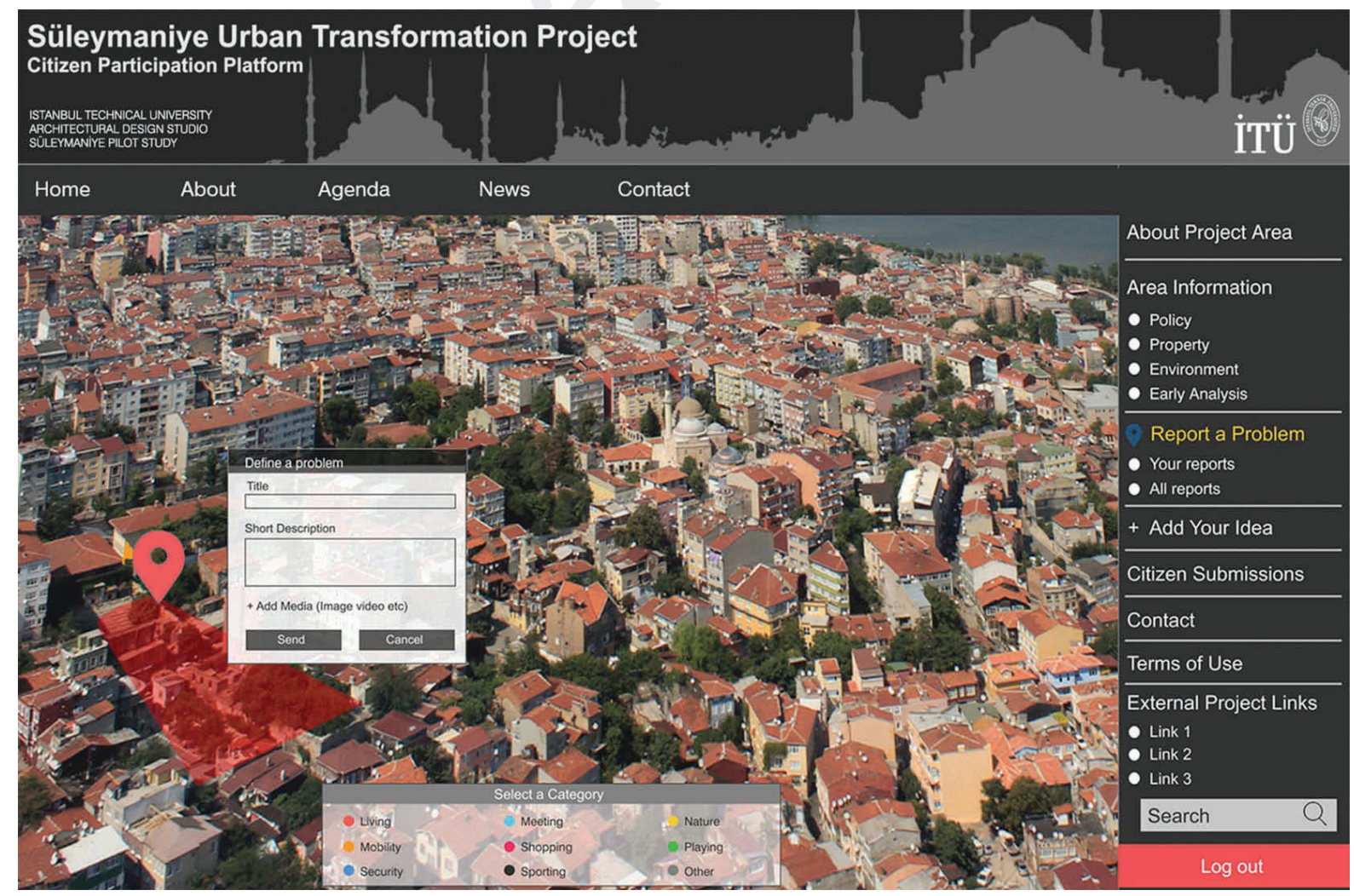

Figure 6. The user interface of cloud-based participation platform. 
and conflicts regarding the exclusion of participants can be eliminated.

\subsubsection{IE 2. Mobile participation application.}

Mobile internet and mobile devices are already used extensively by the Turkish population. Using mobile devices for participation purposes can involve more participants in urban transformation processes, so we propose a mobile participation application as a mobile version of cloud-based participation platforms (Figure 7). However, since mobile devices are limited by screen size, processor power and memory capacity (Gün et al. 2019), we do not offer relatively complex functions such as designing 3D objects on this application.

\subsubsection{IE 3. Mobile field data collection apps.}

Most urban transformation areas in Istanbul not only have physical vulnerabilities but also have social and environmental requirements. In our model, we propose that social workers, who work as field staff for municipalities or the ministry, should collect data in various themes in the field, and thus identify needs and requirements such as public space requirements, spatial problems, and social facility deficiencies. To do so, we propose mobile field data collection apps, which can be customised for specific subjects in order that social workers can collect data on site collaboratively and share it with the experts simultaneously (Figure 8).
5.2.3.4. IE 4. Expert collaboration platform. One of the key components of our model is the collaboration of different expert groups such as municipal officials, project managers and design teams in order to enable interdisciplinary and datadriven decision-making processes. We propose an expert collaboration platform that has two main functions: (1) an urban transformation data panel that enables multiple expert groups to upload data and access to the data pool in one shared interface like city dashboards, and (2) an expert integration and deliberation area that allows expert groups to join different group workspaces to exchange opinions and deliberate over project issues (Figure 9).

The expert collaboration platform incorporates a variety of data sources such as physical analysis, statistics, social media data and socio-spatial analysis of the area. It allows expert groups to view all data in one space, juxtapose and superimpose different data layers for visualisation and analyse data and so experts can generate new knowledge. Multiple expert groups can use this platform to make decisions about urban transformation issues in an interdisciplinary way. It can be used for project management because it enables project managers to monitor all data flows, manage workflows and actors, and contact other experts (Figure 10).
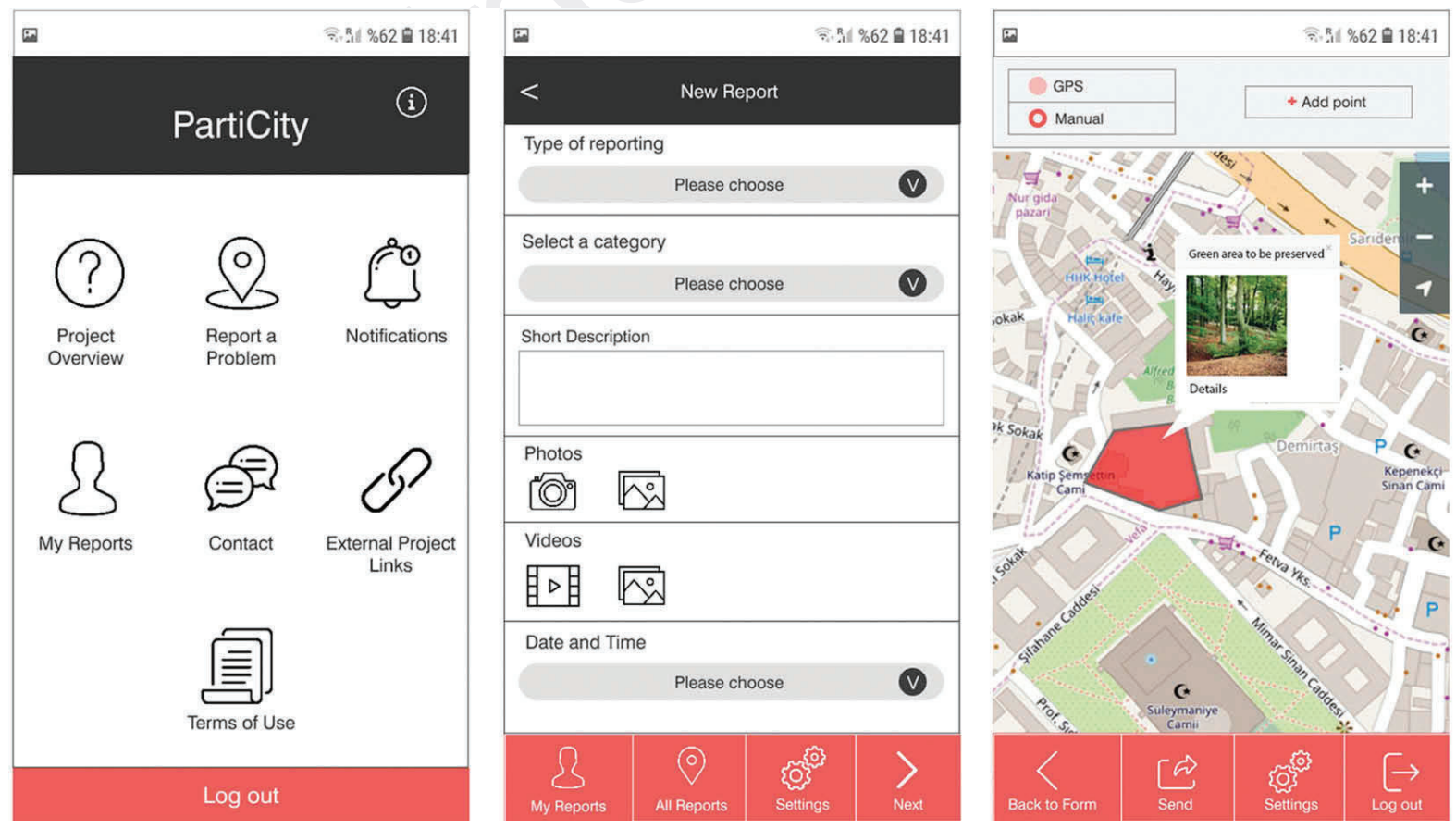

Figure 7. The user interface of the mobile participation application. 


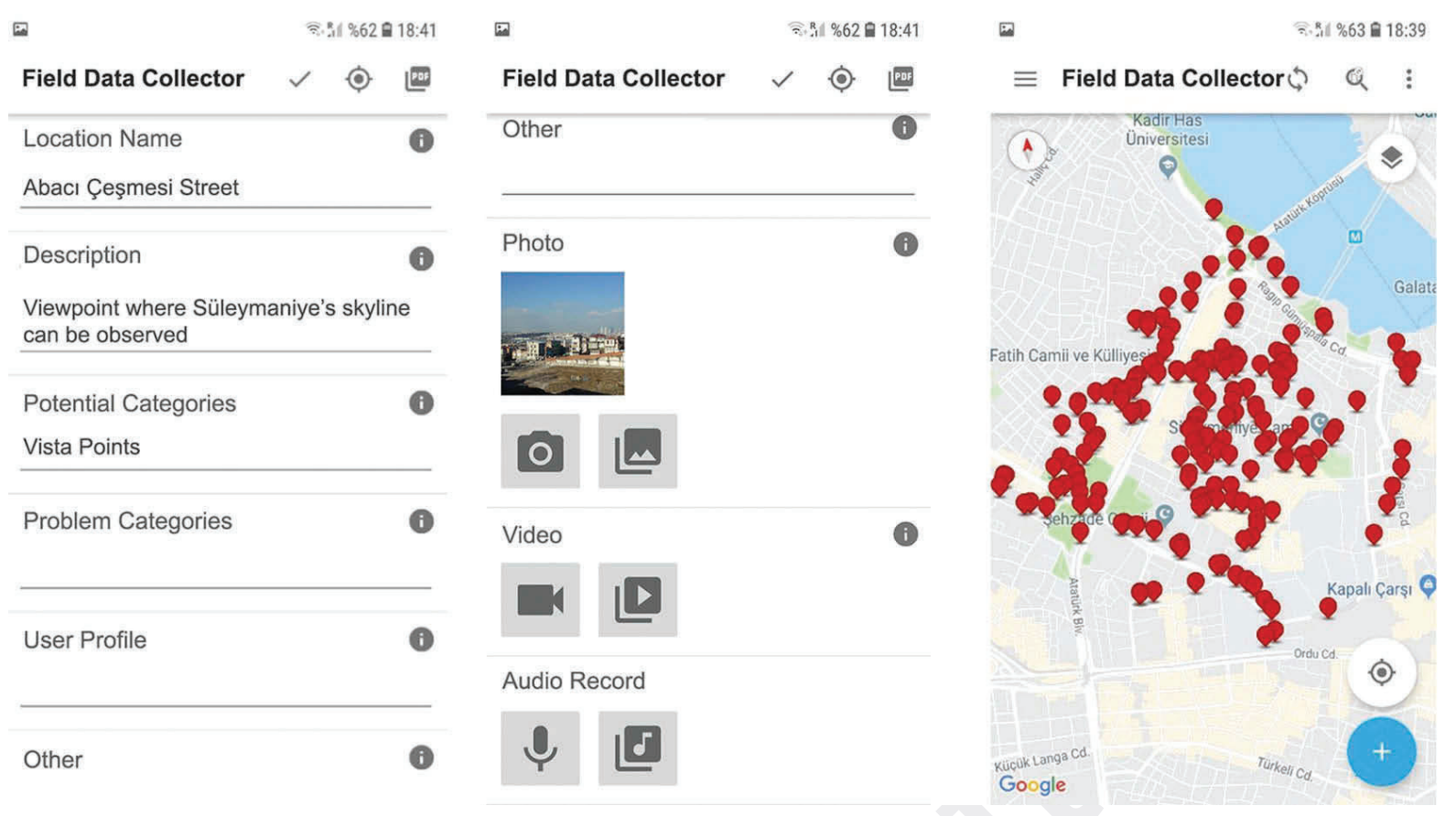

Figure 8. Mobile field data collection application (developed by the authors at Fulcrum).

\subsubsection{Proposed actions and process}

After introducing the candidate architecture of our model, actors and interaction environments, we identified several participatory actions embedded in action flows in the urban transformation process. We determined the actors involved in each action, and identified tools and interaction environments for actions and their integration into the process. To do so, we classified the participatory actions by design stage: actions that support pre-design stages, and actions that support design creation stages. There are two main types of actions: citizen actions based on the direct participation of citizens, and expert actions based on the collaboration and deliberations of expert groups (Figure 11).

\subsubsection{Participatory actions in the pre-design stage}

5.2.5.1. Problem reporting. One of the main aims of urban transformation projects is to increase the quality of built environments. Doing so requires addressing and resolving current problems. In our model, citizens report the problems that they observe in categories such as environmental, social and security-related issues using the web-based participation platform or the mobile participation application. They add placemarks and descriptive text, send geolocated photos that depict problems, and comment on or rate other notifications. This action generates first-hand data about problems from the perspectives of citizens and provides important input for analysing the current situation of urban transformation areas.

5.2.5.2. Identifying needs and requirements. It is important to identify needs and requirements in the predesign stages so as to provide comprehensive data for the design stage. To do so, social workers collect geolocated data regarding the problems, needs and requirements of the citizens and their neighbourhoods through the use of mobile field data collection apps based on their observations or by interacting with citizens. This action enables expert groups to collect information about the needs and requirements of areas in different thematic layers.

5.2.3.3. Mapping socio-spatial relations. One of the principles of our model (principle 3 ) is to grasp and visualise the 'spirit' of urban transformation areas. This action aims to find answers to the following questions: Are there any unique socio-spatial features particular to this area? How do people use their neighbourhood? How do people socialise, live, and work? What is used intensively or abandoned in the current situation? How do people use their homes? This data is also collected through the use of mobile field data collection apps by participation architects and social workers. This action is carried out in different 


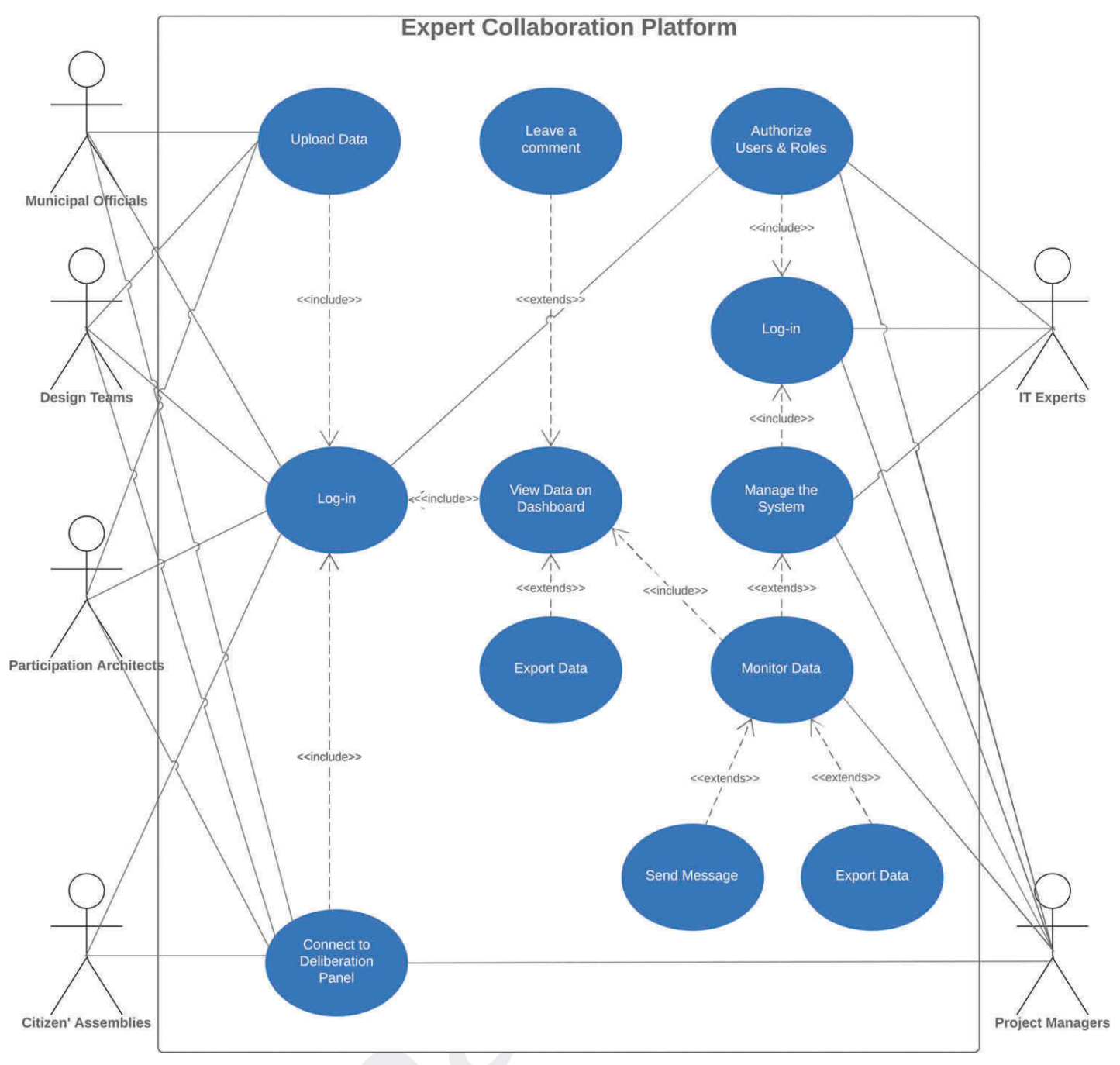

Figure 9. Use case UML diagram of the expert collaboration platform.

activities, by field observation and with on-site workshops that involve collaboration between citizens and expert groups. This action enables expert groups to understand the socio-spatial characteristics of areas and so it makes a significant contribution to the creation of meaningful places.

5.2.5.4. Social media analysis. A plethora of social media networks are already being used extensively by the Turkish population. Citizens who live in urban transformation areas prefer to disseminate information, and to express their desires and needs by creating networks on social media channels because there they are not subject to barriers or constraints (Official 9, personal communication, 23 January 2019). Thus, one of our model's participatory actions is social media analysis. We aim to use the power of social media not only to disseminate information, but also to understand the ideas, thoughts and feelings of community members about urban transformation projects. This action not only empowers Turkish citizens to get information about urban transformation issues, but it also enables expert groups to better understand the social reality.

\subsubsection{Participatory actions in the design creation stage}

5.2.6.1. Collecting desires and expectations from the project. In participatory design processes, users are given a new position of 'expert in his/her experience' and plays an effective role in idea generation (Sanders and Stappers 2008). One of the central aims of our model is to develop planning and design solutions that meet the desires and expectations of citizens. We propose an action that enables citizens to submit their desires and expectations from the renewal project of their neighbourhood on a cloud- 


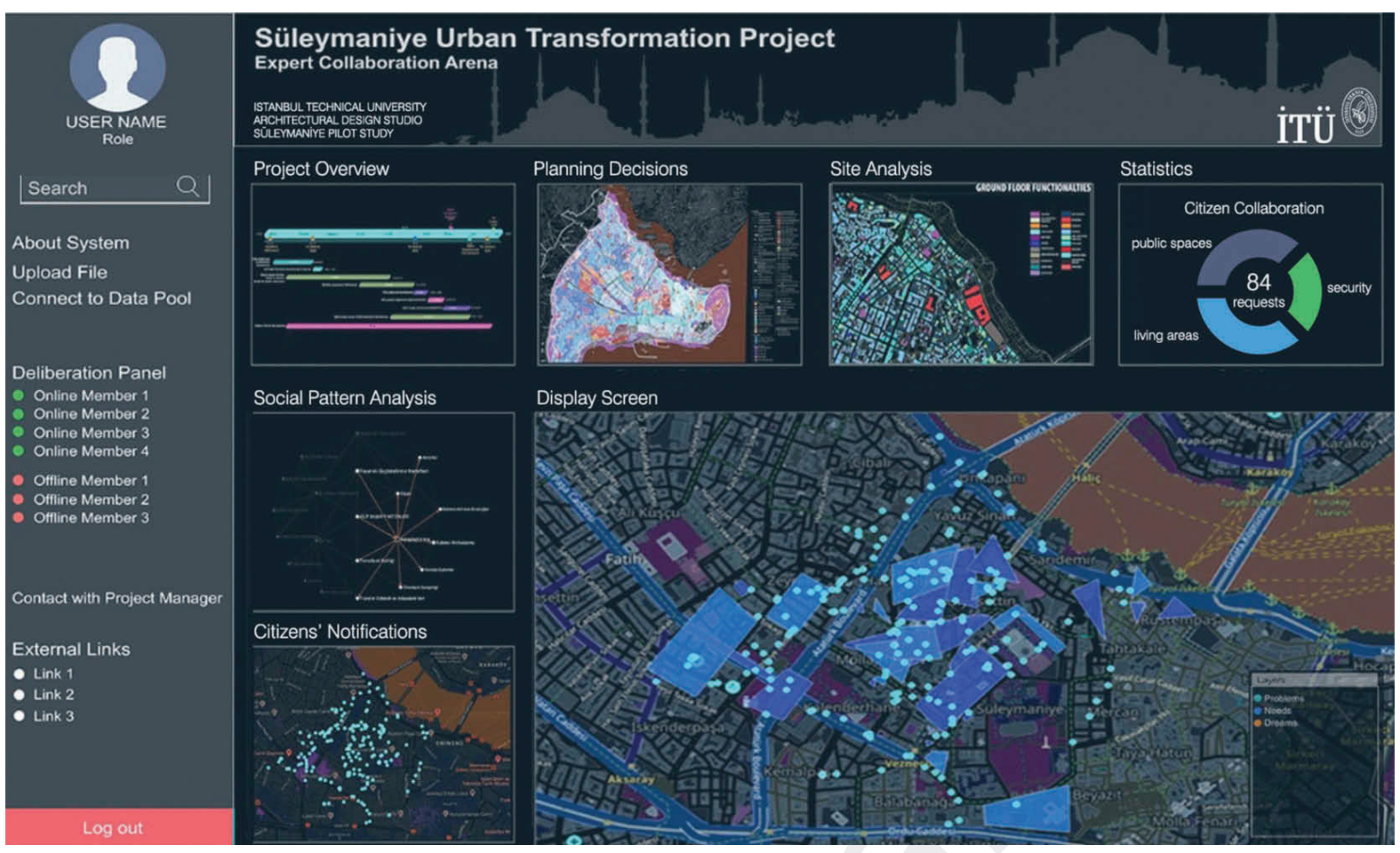

Figure 10. User interface of the expert collaboration platform.

based participation platform in a variety of categories, such as living, nature, working, socialising. Citizens can share their design proposals and suggestions, view the other citizens' submissions, comment on them and vote for them. This action not only encourages citizens to involve their thoughts and ideas in design processes, but it also enables expert groups to collect and monitor the ideas and thoughts of citizens in different categories.

\subsubsection{Identifying planning and design criteria.} In this model, a wide variety of data are produced and collected in the analysis and pre-design stages to be used in design stage so we propose an expert action that makes it possible to identify the key issues, planning and design criteria based on data, the deliberations of experts and current legal and planning constraints. The expert collaboration platform is at the centre of this action. This action creates a bridge between the data collected and the preparation of urban design projects.

\subsubsection{Providing feedback on design alterna-} tives. Our model is intended to create iterative, agile and reflective design process. Thus, citizens provide feedback by adding placemarks and descriptive comments concerning the planning and design project alternatives shared by design teams on cloud-based participation platform. Design teams update their projects by considering the citizens' feedback. This action makes it possible not only to enhance citizens' satisfaction with and trust in the process, but it also enables design professionals to learn about public attitudes and project acceptance before the later stages of design creation.

\subsection{The evaluative criteria for better ICT-enabled participatory urban transformation practices}

After integrating the literature review, interviews, urban transformation regulations, requirements, and principles identified, we addressed several evaluative criteria for better ICT-integrated participatory urban transformation practices: (1) an objective, inclusive and data-driven process, (2) user motivation and facilitation, (3) equal representation, (4) trust and (5) protecting data privacy (Table 2 ).

\section{Conclusions and future directions}

Participatory design concepts and practices have been developed and implemented mainly in the 


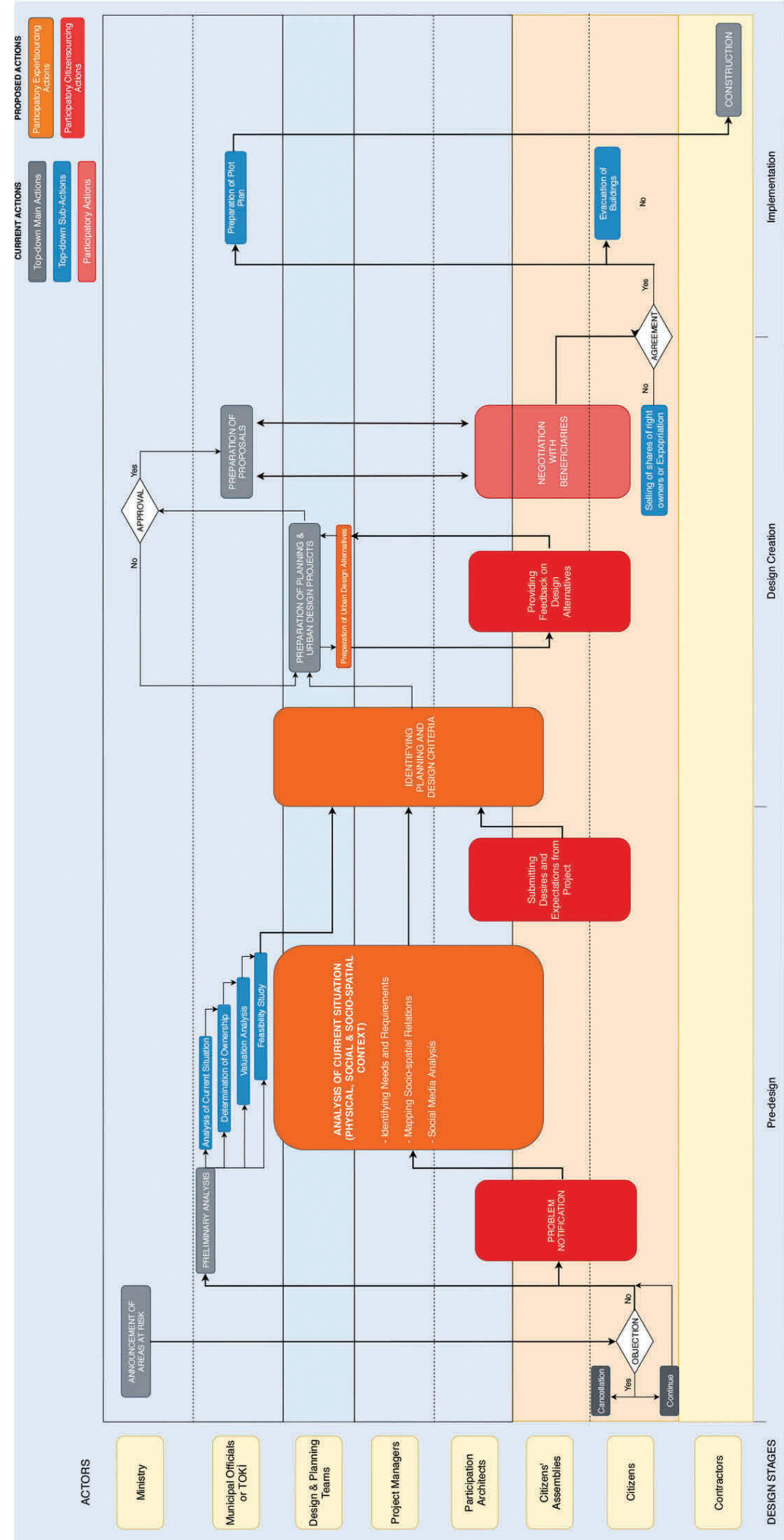

Figure 11. Action flow of the model. 
Table 2. The evaluative criteria for better urban transformation practices in Istanbul.

\begin{tabular}{|c|c|}
\hline Evaluative criteria & Questions applied to the process for better practices \\
\hline \multirow{3}{*}{$\begin{array}{l}\text { An Objective, Inclusive } \\
\text { and } \\
\text { Data-driven Process }\end{array}$} & Is the objective evaluative criteria utilised to filter and analyse the collected data? \\
\hline & Is an objective and data-driven decision-making process realised in collaboration with different expert groups? \\
\hline & $\begin{array}{l}\text { Is data for users and their neighbourhoods' socio-spatial characteristics collected and integrated into the } \\
\text { design process? }\end{array}$ \\
\hline \multirow[t]{7}{*}{$\begin{array}{l}\text { User Motivation and } \\
\text { Facilitation }\end{array}$} & $\begin{array}{l}\text { Are online/on-site activities carried out to sustain the long term motivation of citizens to participate in the } \\
\text { transformation process? }\end{array}$ \\
\hline & Are activities, tools and methods identified considering the capabilities of different participant groups? \\
\hline & Are facilitator groups involved in the process to mediate the activities? \\
\hline & $\begin{array}{l}\text { Are necessary outreach and promotion activities being done to raise awareness and enable the inclusion of } \\
\text { larger community groups? }\end{array}$ \\
\hline & Is the knowledge commons shared with community groups in an accessible and easy-to-understand format? \\
\hline & Are the required design environments and functions provided to citizens? \\
\hline & $\begin{array}{l}\text { Are training and collective envisioning activities conducted to enable participants to gain new insights and } \\
\text { provide high-quality input to participatory design processes? }\end{array}$ \\
\hline \multirow[t]{2}{*}{ Equal Representation } & Are the needs, desires and expectations of all interest groups represented equally in overall process? \\
\hline & $\begin{array}{l}\text { Are on-site activities carried out so that interest groups who lack the skills to use ICT-enabled tools can be } \\
\text { involved in the participatory design activities? }\end{array}$ \\
\hline \multirow[t]{2}{*}{ Trust } & Can participants follow up whether their ideas and feedback are integrated into the design process? \\
\hline & Are all urban transformation steps and actions shared with participants transparently? \\
\hline Data Privacy & $\begin{array}{l}\text { Is the knowledge commons managed in line with General Data Production Regulation-GDPR }(2016 / 679) \text { and } \\
\text { protected from the data surveillance effect and use for commercial purposes by third parties? }\end{array}$ \\
\hline
\end{tabular}

'Global North' (Winschiers 2006). Only limited research has been conducted in developing countries and in the Global South and the countries bordering the Global 'Brandt Line' such as Turkey. In this context, the established participatory design approaches cannot be simply imported and applied in these settings (Messeter et al. 2012).

There are serious difficulties in facilitating ICTenabled participatory design practices and crowdsourcing in these countries, particularly in Turkey such as the lack of democracy, culture of participation and collaboration between the government, civil society and universities, limited institutionalisation of participation, low level of education, cultural heterogeneities (especially after the refugee crisis), lack of data and the authorities' unwillingness to share data, the limited motivation of the authorities to include citizen opinions in urban design and planning and the need for clear strategies and guiding principles.

An important knowledge contribution of this study is to address alternative ways to foster wider participation of Turkish citizens in the urban transformation process. In order to design a digital participatory design system, it is quintessential to consider the specific cultural and political circumstances of
Turkey, its forms of government and governance. Although the government of Turkey aims to improve its forms of governance policies by following decentralisation policies, citizens and civil society have still been systematically isolated from urban-architectural design and decision-making processes. This exclusion led to a shared sense of alienation and a lack of trust in participation, a phenomenon also observed in the Turkish context as well as in the European contexts (Pak and Verbeke 2014).

Trust is a key factor which affects the participation processes. The perceived trustworthiness of the participation processes and the technological tools is interlinked with the possibilities given to the citizens in goalsetting, ensuring representation equality as well as privacy matters (Pak and Verbeke 2014). Furthermore, status, age and experience differences between the stakeholders is another key issue which influences the trust in participation (Jones et al. 2013). Reflecting on these facts, enabling ICT-based participatory processes in Turkey is a threefold challenge which requires:

(1) to guarantee that introducing ICT-based participatory processes improves the relatively undemocratic state of urban spatial production by sufficiently 
including the input of citizens and other relevant stakeholders (to provide representation equality)

(2) to ease the pressure on the citizens living under a flawed democratic rule and motivate them to participate in and express their concerns on social and spatial matters (enabling trust, facilitating sufficient representation)

(3) to ensure the citizens that technological tools and collected data will not disempower the citizens (to protect privacy)

In order to address the challenges indicated above, this study introduces specific design elements and features tailored for the Turkish context. Meticulously studying each legal step, the proposed actions suggest how each legal step can be made more participatory and provides solid actions and tools to enable this goal. In this model, we propose several strategies to avoid the use of ICTs as a means to broaden the theatre of participation (Gaffney and Robertson 2018). The model stipulates extra actions for 'blended' awareness-raising and promoting inclusion: digital and on-site activities to reach the diverse, disadvantaged and underprivileged members of the Turkish society. By introducing ICT-enabled expert-sourcing and integrating several reliable actors, university researchers, urban activists, and neighbourhood representatives, for gathering data and facilitating the process for real-world projects as a key solution, the model bridges the collaboration gap between the government, civil society, and universities and paving the road to citizen-centred 'quadruple helix collaboration'.

By reframing data, information, and knowledge produced by the citizens as a knowledge commons, the model brings in a paradigm shift in digital authorship and ownership. By introducing this shift and developing strategies to protect data privacy, we offer the use of blockchain technology for data management. This can prevent the misuse of data and enable data privacy by anonymising the users' contributions and giving citizens the right to own and control over their data. Therefore, citizens can participate in the process without being subjected to surveillance.

The model also describes a technological framework with several interaction environments. Using these and acting as interfaces, the experts give voice to the citizens and other stakeholders. All of the data regarding the urban transformation process, such as desires and expectations of the citizens and urban transformation decisions, will be shared through the use of these platforms in a transparent way. This inherently enables public pressure on decision-makers by increasing citizens' testimony. These features of the proposed model not only empower citizens by involving them in the process but also make the urban transformation process more reliable. Furthermore, by integrating interactive dashboards visualising data, the proposed model enables not only to maximise the use and impact of ICT-enabled participation but also to involve a diverse range of actors and authorities thus increasing the motivation of these actors to accept and implement such practices.

By developing the model through constructive dialogue and cooperation with the members of the municipal and government agencies and leading experts, this research study raises awareness on and collects support for locally situated participatory work in action not only in urban design and planning but also in the design of the participatory processes as well. Future research can use this model as a guide for urban transformation practices in Istanbul. The components of the model may vary by specific conditions such as the digital literacy of community groups, the ownership of areas, the participants' knowledge about design issues and the socio-spatial context of areas. Our future research direction is to test our model with the collaboration of real stakeholders such as users, municipal officials and design teams with an indepth field study that will examine the model's components, and the reactions of the stakeholder groups. To do this, we are currently negotiating with officials from Beylikdüzü Municipality and other real stakeholders.

\section{Note}

1. In this study, all information about interviewee are coded in order to protect their personal data.

\section{Disclosure statement}

No potential conflict of interest was reported by the authors.

\section{Funding}

This work was supported by the [Scientific and Technological Research Council of Turkey (TUBITAK)] under Grant [number 1059B141700622]. It is produced during the 12-month research visit of the first author. This study also integrated knowledge created through the post-doctoral Research Project conducted at KU Leuven, Faculty of Architecture Campus Brussels with the title "A Virtual Environment for the Analysis and Evaluation of Alternative Urban Development Projects" which was supported by the [INNOVIRIS agency of Brussels Capital Region] under 
Grant [number 3E160653] advised by Johan Verbeke and Burak Pak.

\section{Notes on contributors}

Ahmet Gün holds a PhD from ITU Faculty of Architecture. He taught architectural design studios at Istanbul Technical University (ITU) School of Architecture between 2014-2019. After he completed his bachelor's degree in Architecture (2012), he received master's degree in Urban Design (2014) at Istanbul Technical University (ITU). During his Ph.D period, he carried out his research as a "visiting researcher" at KU Leuven with his co-supervisor, Prof. Burak Pak, between March 2018May 2019. Moreover, he organized a track in JaneJacobs 100 Conference which took place at The Delft University of Technology, The Netherlands. In his Ph.D. dissertation, he developed an ICT-integrated participatory design model for urban transformation areas in Turkey. His current research interest varies from participation in architectural design, bottom-up practices in urban interventions, crowdsourcing, Ict-enabled participatory design, digital participation platforms.

Burak Pak is a Professor of Architectural Collaborative Design, Collective Spaces and Digital Media at KU Leuven Faculty of Architecture. He holds a PhD from ITU Faculty of Architecture. After working at Carnegie Mellon University School of Architecture and Texas A\&M University VIZLab as a Visiting Scholar, he worked as a post-doctoral research fellow (INNOVIRIS) at KU Leuven Faculty of Architecture on "Alternative Urban Projects for the Brussels Capital Region". He is currently teaching design studio courses and running several international and national research projects in Brussels and Ghent Campuses. His research focuses on enabling inclusion in and through design. Co-creation and co-design plays a central role in the research projects he participates in through which he aims to integrate social design practices, education and research. Examples of the research projects he is involved in are: "Co-creating \& Building Solidary Housing for Homeless" (INNOVIRIS Co-create) and "Incubators of Public Spaces" (JPIUrban Europe).

Yüksel Demir currently works as an Associate Professor in ITU Department of Architecture (2012-Present) and served as the head of the department of Fine Arts in ITU (2007-2016). Under his administration, the department opened elective art courses for all engineering students of ITU. He took part in the development process of interdisciplinary first year basic design studio (TES) in ITU department of Architecture (2000-2004). Demir worked in Politecnico Di Milano DIAP (now DASTU) as a guest professor (2010-2015), was a visiting professor in Anadolu University, Department of Architecture (2009-2013), and Auburn University CADC (2016 Fall \& 2017 Fall). He founded ITU MardINT Interdisciplinary Research and Development Center (2005). Assigned as advisor to the rector (2014 - Present). Initiated the establishment process of ITU Polar Research Center Polrec (2014). Managed several urban and Architectural Design projects. His works and interviews were published in several national and international publications; participated in several national and international scientific meetings, gave lectures in national and international institutions, won national and international awards. He continues to work in the fields of Architectural Design, ICT in Design, and Art [theory \& practice]. Currently is coordinating the establishment of Turkish Antarctic Research Station, and is working for the transformation of ITU to a research university.

\section{ORCID}

Ahmet Gün (iD) http://orcid.org/0000-0003-1520-1756

Burak Pak (D) http://orcid.org/0000-0002-2901-1032

\section{References}

Adanalı Y. 2013. Urban transformation and law on disaster prevention: a pretext for lucrative investment, perspective. Pol Anal Commentary Turkey. 3:37-39.

Ashley H. 2009. Change at hand: web 2.0 for development. Nottingham: Russell Press. Vol. 59. IIED.

Balaban MŞ. 2019. Hazard-prone cities and recent challenges in the case of urban transformation experience of Turkey. In: Ozdemir Sarı OB, Ozdemir S, Uzun N, editors. Urban and regional planning in Turkey. Cham: Springer; p. 235-259.

Bannon LJ, Ehn P. 2012. Design matters in participatory design. In: Simonsen J, Robertson T, editors. Routledge handbook of participatory design. London: Routledge; p. 37-63.

[EM-DAT] The Emergency Events Database. (2019). Disaster profile of Turkey between 1900-2019. www.emdat.be.

Brabham DC. 2010. Moving the crowd at threadless: motivations for participation in a crowdsourcing application. Information. Commun Soc. 13(8):1122-1145.

Desouza KC, Bhagwatwar A. 2014. Technology-enabled participatory platforms for civic engagement: the case of US cities. J Urban Technol. 21(4):25-50. doi:10.1080/ 10630732.2014 .954898$.

Elicin Y. 2014. Neoliberal transformation of the Turkish city through the urban transformation act. Habitat Int. 41:150-155. doi:10.1016/j.habitatint.2013.07.006.

Elwood S, Leszczynski A. 2011. Privacy, reconsidered: new representations, data practices, and the geoweb. Geoforum; J Phys Hum Reg Geosci. 42(1):6-15. doi:10.1016/j.geoforum.2010.08.003.

Erdik M. 2013. Earthquake risk in Turkey. Science. 341 (6147):724-725. doi:10.1126/science.1238945.

Ertiö TP. 2015. Participatory apps for urban planning-space for improvement. Plann Pract Res. 30(3):303-321. doi:10.1080/ 02697459.2015.1052942.

Evans-Cowley J, Hollander J. 2010. The new generation of public participation: internet based participation tools. Plann Pract Res. 25(3):397-408. doi:10.1080/ 02697459.2010 .503432$.

Falco E, Kleinhans R. 2018. Digital participatory platforms for co-production in urban development: A systematic review. Int J E-Plann Res. 7(3):1-21. doi:10.4018/IJEPR.

[GDPR] General Data Protection Regulation. 2016. https://gdprinfo.eu/.

Foth M. 2018. Participatory urban informatics: towards citizen-ability. Smart Sustainable Built Environ. 7(1):4-19. doi:10.1108/SASBE-10-2017-0051. 
Foth M, Adkins B. 2006. A research design to build effective partnerships between city planners, developers, government and urban neighbourhood communities. J Community Inf. 2:2.

Foth M, Brynskov M. 2016. Participatory action research for civic engagement. In: Gordon E, Mihailidis P, editors. Civic media: technology, design, practice. Cambridge, MA: MIT Press; p. 563-580.

Gaffney C, Robertson C. 2018. Smarter than smart: Rio de Janeiro's flawed emergence as a smart city. Journal of Urban Technology. 25(3):47-64.

Goldsmith S, Crawford S. 2014. The responsive city: engaging communities through data-smart governance. San Francisco: John Wiley \& Sons.

Gün A, Demir Y, Pak B. 2019. Urban design empowerment through ICT-based platforms in europe. International journal of urban sciences. p. 1-27. doi:10.1080/12265934.2019.1604250

Güzey Ö. 2016. The last round in restructuring the city: urban regeneration becomes a state policy of disaster prevention in Turkey. Cities. 50:40-53. doi:10.1016/j.cities.2015.08.010.

Habertürk (2017). Mehmet Özhaseki: yeni yasanın eli kulağında, 7.5 milyon bina yenilenecek [The minister of environment and urbanization: 7,5 million housing unit will be rebuilt]. https://www.haberturk.com/gundem/haber/1600758-meh met-ozhaseki-den-haberturk-tv-ye-aciklamalar\#

Hasler S, Chenal J, Soutter M. 2017. Digital tools as a means to foster inclusive, data informed urban planning. Civ Eng Archit. 5(6):230-239. doi:10.13189/cea.2017.050605.

Healey P. 2003. Collaborative planning in perspective. Plann Theory. 2(2):101-123. doi:10.1177/14730952030022002.

Hess C, Ostrom E. 2007. Introduction: an overview of the knowledge commons. Understanding Knowl Commons. In: Hess C, Ostrom E, editors. Understanding Knowledge as a Commons. Cambridge, MA: MIT Press; 3-26.

Hirsch T. 2011. More than friends: social and mobile media for activist organizations. In: Foth $M$, et al., editors. Social Butterfly to Engaged Citizen: Urban Informatics, Social Media, Ubiquitous Computing, and Mobile Technology to Support Citizen Engagement. MIT Press; p. 135-150.

Houghton K, Miller E, Foth M. 2014. Integrating ICT into the planning process: impacts, opportunities and challenges. Aust Plann. 51(1):24-33. doi:10.1080/07293682.2013.770771.

Hurriyet. 2018. Yılda 500 bin konut yeniden üretilecek $(500,000$ housing unit will be reconstructed a year). http://www.hurriyet. com.tr/ekonomi/yilda-500-bin-konut-yeniden-uretilecek $-40840334$.

Jones PB, Petrescu D, Till J. 2013. Architecture and participation. New York: Routledge.

Karaman O. 2014. Resisting urban renewal in Istanbul. Urban Geogr. 35(2):290-310. doi:10.1080/02723638.2013. 865444.

Kemp S (2017). Digital in 2017: global overview we are social. We are Soc. Hootsuite. https://wearesocial.com/uk/special-reports /digital-in-2017-global-overview

Kirlidog M. 2008. Developing regional communities in Turkey. In Tan FB, editor. Global information technologies: concepts, methodologies, tools, and applications. London: IGI Global; p. 671-678.

Kitchin R. 2014. The real-time city? Big data and smart urbanism. GeoJournal. 79(1):1-14. doi:10.1007/s10708-013-9516-8.

Kitchin R (2015) Data-driven, networked urbanism. Programmable City Working Paper 14. Maynooth University.
Law D (2014). Portal for ArcGIS 101. https://www.esri.com/esrinews/arcuser/winter-2014/portal-for-arcgis-101.

Leszczynski A. 2015. Spatial big data and anxieties of control. Environ Plann D Soc Space. 33(6):965-984. doi:10.1177/ 0263775815595814.

Lovering J, Türkmen H. 2011. Bulldozer neo-liberalism in Istanbul: the state-led construction of property markets, and the displacement of the urban poor. International Planning Studies. 16(1):73-96. doi:10.1080/13563475.2 011.552477.

Meeus B, Pak B. 2018. Reflections on the counter-mapping of urban 'arrival neighborhoods' through Geoweb 2.0 in Brussels and Ghent. In: Devisch et al., editors. Participatory design theory: Using Technology and Social Media to Foster Civic Engagement. London: Routledge; p. 40-55.

Melgaço L, Willis KS. 2015. ICTs and technical agency: A case study of a rural Brazilian community. In: Foth $M$, et al., editors. Citizen's right to the digital city. Singapore: Springer; $p$. 101-117.

Messeter J, Claassen H, Finnan C. 2012. Participatory design in the developing world: issues and opportunities from case studies of adapting Nordic participatory approaches to a South African context. In SANORD international symposium 2012 (South African-Nordic Centre); Aarhus University, Denmark.

Mitchell H, Odendaal N. 2015. From the fringes: south Africa's smart township citizens. In: Foth $M$, et al., editors. Citizen's right to the digital city. Singapore: Springer; p. 137-159.

Nunes Silva C, Ed.. 2018. New approaches, methods, and tools in urban E-planning. Hershey, PA, USA: IGI Global.

Official Gazette (2005). Belediye kanunu (municipality law no. 5393). https://www.mevzuat.gov.tr/MevzuatMetin/1.5.5393.pdf

Official Gazette. 2012. Afet riski altındaki alanların dönüştürülmesine ilişkin kanun (The law regarding transformation of areas under disaster risks). http://www.resmiga zete.gov.tr/eskiler/2012/05/20120531-1.htm

Official Gazette. 2013. Afet riski altindaki alanlarin dönüştürülmesi hakkinda kanunun uygulama yönetmeliğinde değişiklik yapilmasina dair yönetmelik [The regulation towards the amendments of regulation for implementation of the law regarding transformation of areas under disaster risks]. http://www.resmigazete.gov. tr/eskiler/2013/07/20130702-3.htm.

Ostrom E, Hess C. 2007. A framework for analyzing the knowledge commons. In: Hess C, Ostrom E, editors. Understanding Knowledge as a Commons. Cambridge, MA: MIT Press; p. 41-81.

Pak B, Chua A, Vande Moere A. 2017. Fixmystreet Brussels: socio-demographic inequality in crowdsourced civic participation. J Urban Technol. 24(2):65-87. doi:10.1080/ 10630732.2016.1270047.

Pak B, Verbeke J. 2014. Geoweb 2.0 for participatory urban design: affordances and critical success factors. Int J Archit Comput. 12(3):283-305. doi:10.1260/1478-0771.12.3.283.

Poplin A. 2012. Playful public participation in urban planning: A case study for online serious games. Comput Environ Urban Syst. 36(3):195-206. doi:10.1016/j.comp envurbsys.2011.10.003.

Rozanski N, Woods E. 2005. Software systems architecture: working with stakeholders using viewpoints and perspectives. Westford, Massachusetts: Addison-Wesley. 
Sanders EBN, Stappers PJ. 2008. Co-creation and the new landscapes of design. Co-design. 4(1):5-18.

Saraçoğlu C, Demirtaş-Milz N. 2014. Disasters as an ideological strategy for governing neoliberal urban transformation in Turkey: insights from Izmir/Kadifekale. Disasters. 38 (1):178-201. doi:10.1111/disa.12038.

Saxton GD, Oh O, Kishore R. 2013. Rules of crowdsourcing: models, issues, and systems of control. Inf Syst Manage. 30 (1):2-20. doi:10.1080/10580530.2013.739883.

Schröder C. 2015. Through space and time: using mobile apps for urban participation. Conference for e-democracy and open government. Donau University, Austria; p. 133-142.

Seltzer E, Mahmoudi D. 2013. Citizen participation, open innovation, and crowdsourcing: challenges and opportunities for planning. J Plann Lit. 28(1):3-18. doi:10.1177/0885412212469112.

Smith RC, Bossen C, Kanstrup AM. 2017. Participatory design in an era of participation. Co-design. 13(2):65-69.

Statista. 2019. Number of internet users in Turkey from 2013 to 2019. https://www.statista.com/statistics/369725/internetusers-turkey/.

Tansel CB. 2019. Reproducing authoritarian neoliberalism in Turkey: urban governance and state restructuring in the shadow of executive centralization. Globalizations. 16 (3):320-335. doi:10.1080/14747731.2018.1502494.

Thinyane M, Bhat K, Goldkind L, Cannanure VK (2018, August). Critical participatory design: reflections on engagement and empowerment in a case of a community based organization. In Proceedings of the 15th participatory design conference; Hesselt \& Genk, Belgium: full papers-volume 1; ACM. p. 2.

Türkün A. 2011. Urban regeneration and hegemonic power relationships. Int Plann Stud. 16(1):61-72. doi:10.1080/ 13563475.2011.552473.
Unsal BO. 2015. State-led urban regeneration in istanbul: Power struggles between interest groups and poor communities. Housing Studies. 30(8):1299-1316.

Wallin S, Horelli L, Saad-Sulonen J. 2010. Introduction-ICTs changing the research and practice of participatory urban planning. In: Wallin S, Horelli L, Saad-Sulonen J, editors. Digital Tools Part Plann. 7-12. Espoo: Centre for Urban and Regional Studies Publications. Aalto University, School of Science and Technology; p. 7-12.

Winschiers H. 2006. The challenges of participatory design in an intercultural context: designing for usability in Namibia. PDC 2006. Trento, Italy; p. 73-76.

Yalçıntan MC (2009). Kentsel Muhalefetin Halleri ve Halsizlikleri [The conditions and weaknesses of urban opposition]. http:// www. planlama.org/index.php/planlamaorgyazlar6/planla maorg-yazlar/57-planlamaorg-yazlar/murat-cemalyalcintan /489-kentsel-muhalefetin-halleri-ve-halsizlikleri.

Yeniemlak. 2017. Fikirtepe Kentsel Dönüşümle Düzene Giriyor [Fikirtepe is going to be renewed through urban transformation]. https://www.yeniemlak.com/fikirtepe-kentseldonusumle-duzene-giriyor-14210-emlak-haberleri

Yildiz S, Kivrak S, Arslan G. 2018. Contribution of built environment design elements to the sustainability of urban renewal projects: model proposal. J Urban Plann Dev. 145 (1):04018045. doi:10.1061/(ASCE)UP.1943-5444.0000493.

Zimprich S. 2018. Blockchain \& e-government - giving citizens control of their data. https://www.dotmagazine.online/ issues/blockchain-e-government/blockchain-e-governmentcitizen-control-of-data.

Zyskind G, Nathan O. 2015. Decentralizing privacy: using blockchain to protect personal data. In: SPW '15: Proceedings of the IEEE security and privacy workshops. NW Washington, DC, United States: IEEE; p. 180-184. 